\title{
The Rofental: a high Alpine research basin (1890-3770 m a.s.I.) in the Ötztal Alps (Austria) with over 150 years of hydrometeorological and glaciological observations
}

\author{
Ulrich Strasser $^{1}$, Thomas Marke ${ }^{1}$, Ludwig Braun ${ }^{3}$, Heidi Escher-Vetter ${ }^{3}$, Irmgard Juen ${ }^{2}$, \\ Michael Kuhn², Fabien Maussion ${ }^{2}$, Christoph Mayer $^{3}$, Lindsey Nicholson $^{2}$, Klaus Niedertscheider ${ }^{4}$, \\ Rudolf Sailer ${ }^{1}$, Johann Stötter ${ }^{1}$, Markus Weber ${ }^{5}$, and Georg Kaser ${ }^{2}$ \\ ${ }^{1}$ Department of Geography, University of Innsbruck, Innsbruck, 6020, Austria \\ ${ }^{2}$ Department of Atmospheric and Cryospheric Sciences, University of Innsbruck, Innsbruck, 6020, Austria \\ ${ }^{3}$ Geodesy and Glaciology, Bavarian Academy of Sciences and Humanities, Munich, 80539, Germany \\ ${ }^{4}$ Hydrographic Service of Tyrol, Innsbruck, 6020, Austria \\ ${ }^{5}$ Photogrammetry and Remote Sensing, Technical University of Munich, Munich, 80333, Germany
}

Correspondence: Ulrich Strasser (ulrich.strasser@uibk.ac.at)

\author{
Received: 3 August 2017 - Discussion started: 21 August 2017 \\ Revised: 26 November 2017 - Accepted: 18 December 2017 - Published: 24 January 2018
}

\begin{abstract}
A comprehensive hydrometeorological and glaciological data set is presented, originating from a multitude of glaciological, meteorological, hydrological and laser scanning recordings at research sites in the Rofental (1891-3772 m a.s.l., Ötztal Alps, Austria). The data sets span a period of 150 years and hence represent a unique time series of rich high-altitude mountain observations. Their collection was originally initiated to support scientific investigation of the glaciers Hintereisferner, Kesselwandferner and Vernagtferner. Annual mass balance, glacier front variation, flow velocities and photographic records of the status of these glaciers were recorded. Later, additional measurements of meteorological and hydrological variables were undertaken, and over time a number of autonomous weather stations and runoff gauges were brought into operation; the available data now comprise records of temperature, relative humidity, short- and longwave radiation, wind speed and direction, air pressure, precipitation, and river water levels. Since 2001, a series of distributed (airborne and terrestrial) laser scans is available, along with associated digital surface models. In 2016 a permanent terrestrial laser scanner was installed on "Im hintern Eis" (3244 m a.s.l.) to continuously observe almost the entire area of Hintereisferner. The data and research undertaken at the sites of investigation in the Rofental area enable combined research of cryospheric, atmospheric and hydrological processes in complex terrain, and support the development of several state-of-the-art glacier mass balance and hydroclimatological models. The institutions taking part in the Rofental research framework promote their site in several international research initiatives. In INARCH (International Network for Alpine Research Catchment Hydrology, http://words.usask.ca/inarch), all original research data sets are now provided to the scientific community according to the Creative Commons Attribution License by means of the PANGAEA repository (https://doi.org/10.1594/PANGAEA.876120).
\end{abstract}




\section{Introduction}

Glaciers in the Rofental, Ötztal Alps, have been under observation since the early 17th century; in particular the Vernagtferner (VF) was known for its dangerous surge-type advances (Richter, 1892) with flow velocities up to $11.5 \mathrm{mday}^{-1}$ (Nicolussi, 2013). In 1599, the tongue of VF reached the valley floor of the Rofental, blocking the valley and forming an ice-dammed lake which burst, causing a catastrophic lake outburst flood (GLOF) on 20 July in 1600 . The painting of VF with its lake that was formed again in summer 1601 is the oldest known image of a glacier worldwide (Fig. 1). The lake was $\sim 1700 \mathrm{~m}$ in length, and the lake level was at $\sim 2260$ m a.s.l. (Nicolussi, 1990). Further advances of VF are documented for the periods around 1680, 1770 (the maximum extent of VF in the little ice age, LIA), 1820 and 1848. Prior to the 19th century, each advance of VF formed the ice dam and lake in the Rofental, and the outflow of this lake was observed due to its dangerous nature (Nicolussi, 2013). The glacier changes were monitored with irregular glacier-front variation recordings.

A milestone in glacier cartography was the map "Der Vernagtferner im Jahre 1889 1:10000", constructed by means of terrestrial photogrammetry (Finsterwalder, 1897). This map showed, for the first time, an entire glacier in large scale with unprecedented details, including the area that became ice-free since the last glacier advance period (Fig. 2a). The first map of Hochjochferner (HJF) (1883) by Blümcke and Hess (1895) and Hintereisferner (HEF) (1894) by Blümcke and Hess (1899) followed shortly afterwards (Fig. 2b). After that, geodetic glacier maps were generated frequently for HEF, KWF and VF (Brunner, 2013; Charalampidis, 2018) ${ }^{1}$. These maps were accompanied by frequent terrestrial photographs of VF between 1897 and 1928, documenting, for example, the last surge of the glacier (1897-1903). From these photographs Weber (2013) and Lindmayer (2015) reconstructed the extent and dynamics of VF for the respective periods. The monitoring of the geometry of the glaciers in the Rofental was accompanied by ice drilling experiments to reconstruct the glacier bed and dynamics (Blümcke and Hess, 1899), and first glacier flow theories were developed (Finsterwalder, 1897; Hess, 1904). With the foundation of the "International Commission for Snow and Ice" (ICSI) (as "International Glacier Commission" in Zürich 1894, renamed in 1948) the observation of glaciers became systemized and internationally coordinated, and the continuous observations of meteorological and hydrological variables began: the first totalizing rain gauge in the Rofental was in-

\footnotetext{
${ }^{1}$ HEF: 1850, 1894, 1920, 1939, 1953, 1962, 1964, 1967, 1969, 1979, 1991, 1997, 2001-2008

KWF: 1939, 1967, 1969, 1979, 1991, 1997, 2001-2008

VF: 1846, 1889, 1897, 1899, 1901, 1904, 1912, 1938, 1954, 1966, 1969, 1972, 1979, 1982, 1990, 1994, 1999, 2002, 2003, 2006, 2009 (bold years available at http://geo.badw.de/vernagtferner-digital/ karten.html)
}

stalled in the village of Vent (1900 ma.s.l.) in 1905, followed by continuous measurements further up in the valley since 1952. The "Combined Water, Ice and Heat Balance Project in the Rofental" became an official initiative of the UNESCO International Hydrological Decade (IHD, 1964 1974) (Hoinkes et al., 1974). Later, it was continued as part of the UNESCO International Hydrological Program (IHP) (http://en.unesco.org/themes/water-security/hydrology). Ablation stakes and pits for mass balance monitoring have been continuously maintained at HEF and Kesselwandferner (KWF) (since 1952), at VF (since 1965), and for short discontinuous periods at HJF. As of 2017, the glacier mass balance time series of HEF, VF and KWF are among the longest uninterrupted series worldwide (Fischer et al., 2015; Mayer et al., 2013a), and several automatic weather stations (AWSs) as well as runoff gauges at VF and in the village of Vent are in continuous operation. These are complemented by a network of historical rain gauges (totalizators) and modern precipitation gauges.

The comprehensive pool of long-term observations available for the Rofental provides the basis for (i) manifold process studies on energy balance, ice dynamics, glacier hydrology and hydraulics (e.g., Kuhn et al., 1985a, b; Kuhn, 1987), (ii) new ground-based and remote sensing monitoring methods (Escher-Vetter and Siebers, 2013; Juen et al., 2013; Helfricht et al., 2014a), (iii) model development and application in glaciological and regional hydrological research (Kaser et al., 2010; Escher-Vetter and Oerter, 2013; Schöber et al., 2014, 2016; Hanzer et al., 2016; Schmieder et al., 2016, 2018), (iv) the evaluation of potential future glacier evolution and changes of the hydrological regime in a changing climate (Weber et al., 2009; Marke et al., 2013; Marzeion and Kaser, 2014; Weber and Prasch, 2015a, b; Hanzer et al., 2017), (v) attributing observed glacier changes to different drivers (Painter et al., 2013; Marzeion et al., 2014a, b) and, finally, (vi) as calibration and validation site for estimating the contribution of glaciers to global sea level rise (Marzeion et al., 2012a, b; Marzeion and Levermann, 2014). For VF, a comprehensive collection of 50 years of significant scientific work of the Commission of Glaciology of the Bavarian Academy of Sciences and Humanities has been edited by Braun and Escher-Vetter (2013). Historical elevation and area changes of HEF, KWF and VF are documented in the Austrian glacier inventories, available for 1969, 1997 and 2006 (Abermann et al., 2009): Between 1969 and 1997, the glacier area in the Rofental decreased from 42.9 to $37.7 \mathrm{~km}^{2}$, corresponding to $12 \%$ (Kuhn et al., 2006); recently, the retreat of the glaciers has accelerated. The key glaciological results for HEF, KWF and VF are reported annually to the World Glacier Monitoring Service (WGMS, http://wgms.ch). The state of HEF and KWF in 2014 is shown in Fig. 3.

In addition to monitoring glacier mass balance with glaciological, geodetical and hydrological methods as well as the long-term recordings of respective variables, the Rofental has been an open laboratory for the development of new method- 


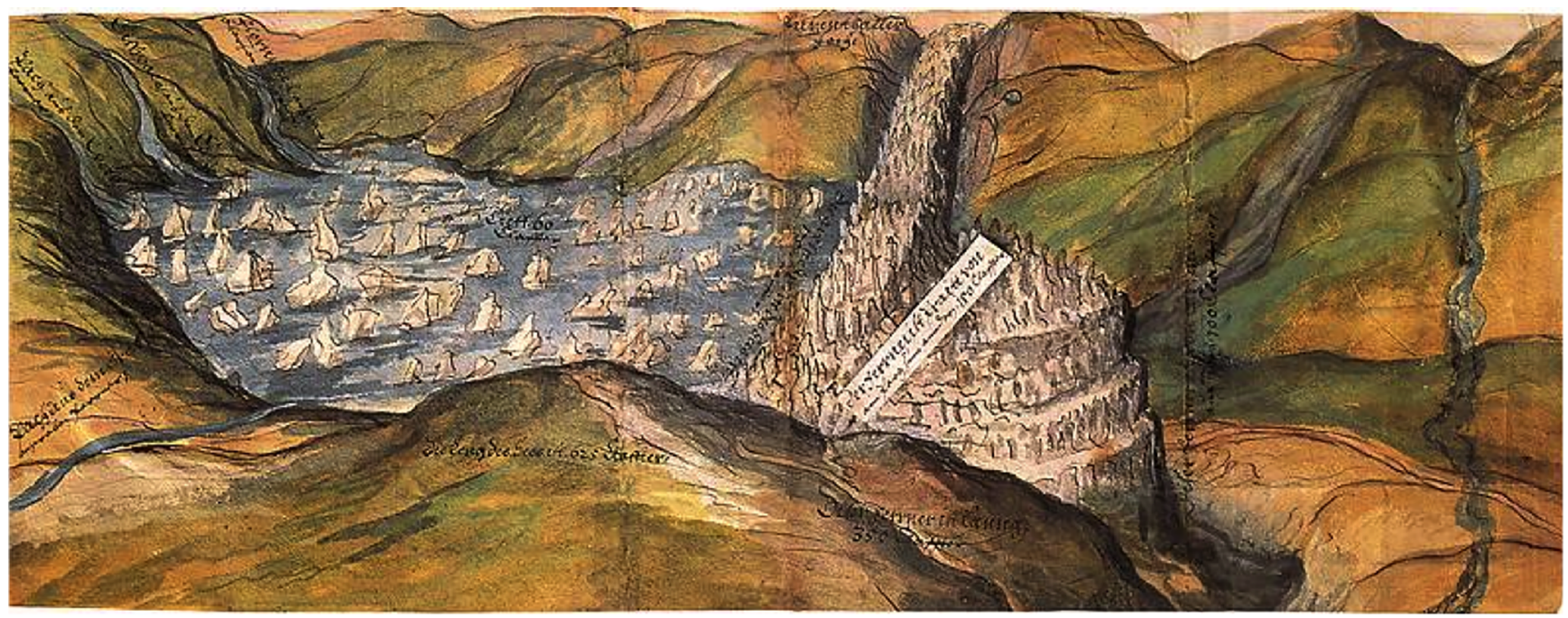

Figure 1. The "Rofentaler Eissee" in 1601, the first known image of a glacier worldwide. Painted in water colors by Abraham Jäger. The original is in the Tiroler Landesmuseum Ferdinandeum in Innsbruck. From Nicolussi (1990).

(a)

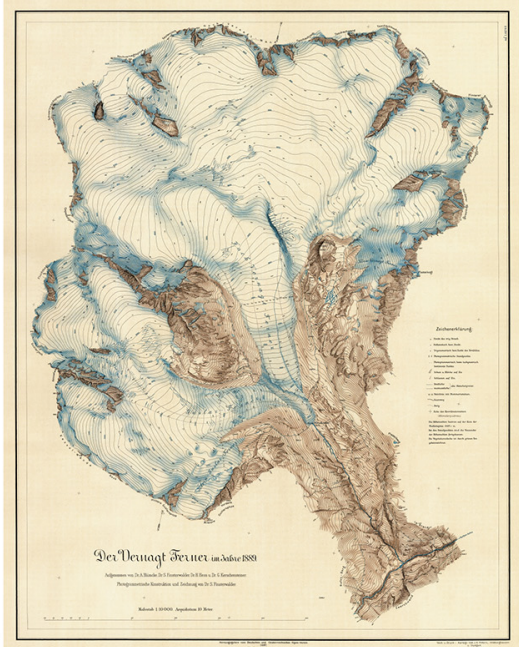

(b)

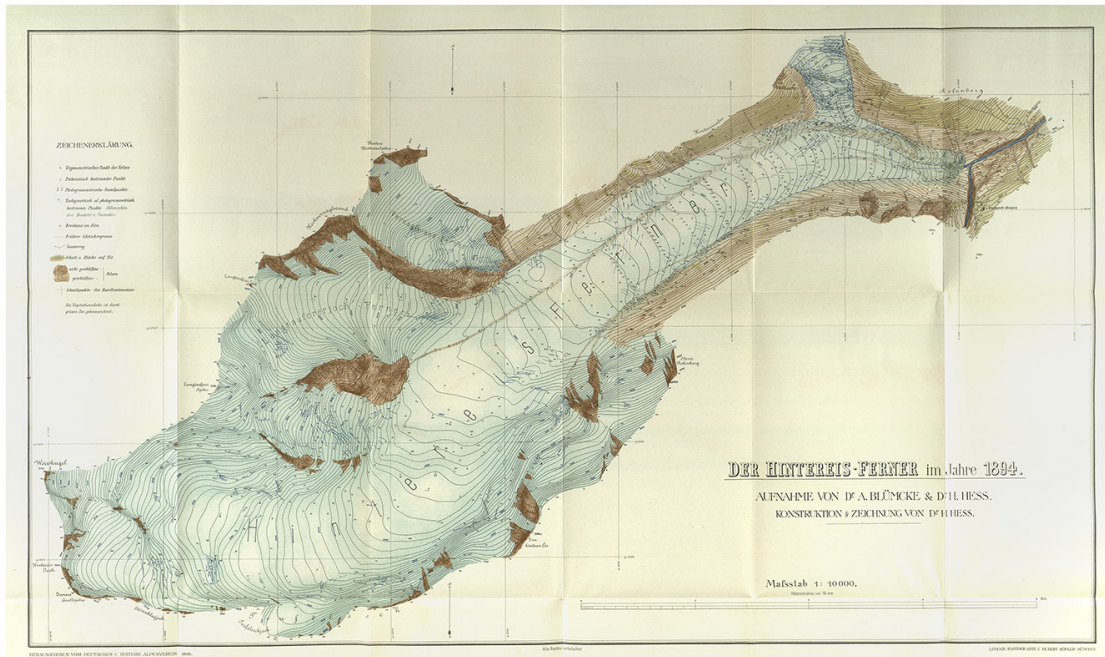

Figure 2. (a) The 1889 map of Vernagtferner showing the entire glacier in large scale: "Der Vernagtferner im Jahre $18891: 10000$ " (Finsterwalder, 1897). (b) “Der Hintereisferner im Jahre 1894” (Blümcke and Hess, 1899).

ologies. For example, a series of airborne lidar-derived highresolution digital terrain models (DTMs) of HEF and its surroundings has been processed spanning 2001-2011 (Geist and Stötter, 2002; Helfricht et al., 2014b; Klug et al., 2017). They are subject to ongoing evaluations and method comparison studies as well as the monitoring and study of periglacial morphodynamics (Sailer et al., 2012, 2014). Since 2016, a permanent terrestrial laser scanning station is operating at $\mathrm{Im}$ hintern Eis (3244 m a.s.l.), allowing for high-resolution, ondemand monitoring of almost the entire surface area of HEF.

All available data for the Rofenal area are placed on a PANGAEA repository (https://doi.org/10.1594/PANGAEA.876120). Recordings of devices which still (as of fall 2017) undergo a test and development phase will be continuously made available in PANGAEA. These data will also be documented as continuation of this publication by means of the ESSD "living data process". The data collection that is already accessible comprises (i) image files, e.g., glacier topography maps, photographs or animations, and diagrams; (ii) raster grids, e.g., spatial data derived from laser scanning, as tabdelimited text files; (iii) time series of point observations, e.g., meteorological and hydrological recordings, as well as calculated results for points or areas such as mass balances, as tab-delimited text files; and (iv) the glacier inventories in ArcGIS shape file format. All data are comprised with the period of coverage, and the exact coordinates of the locations (in latitudes and longitudes). Areas are defined by 


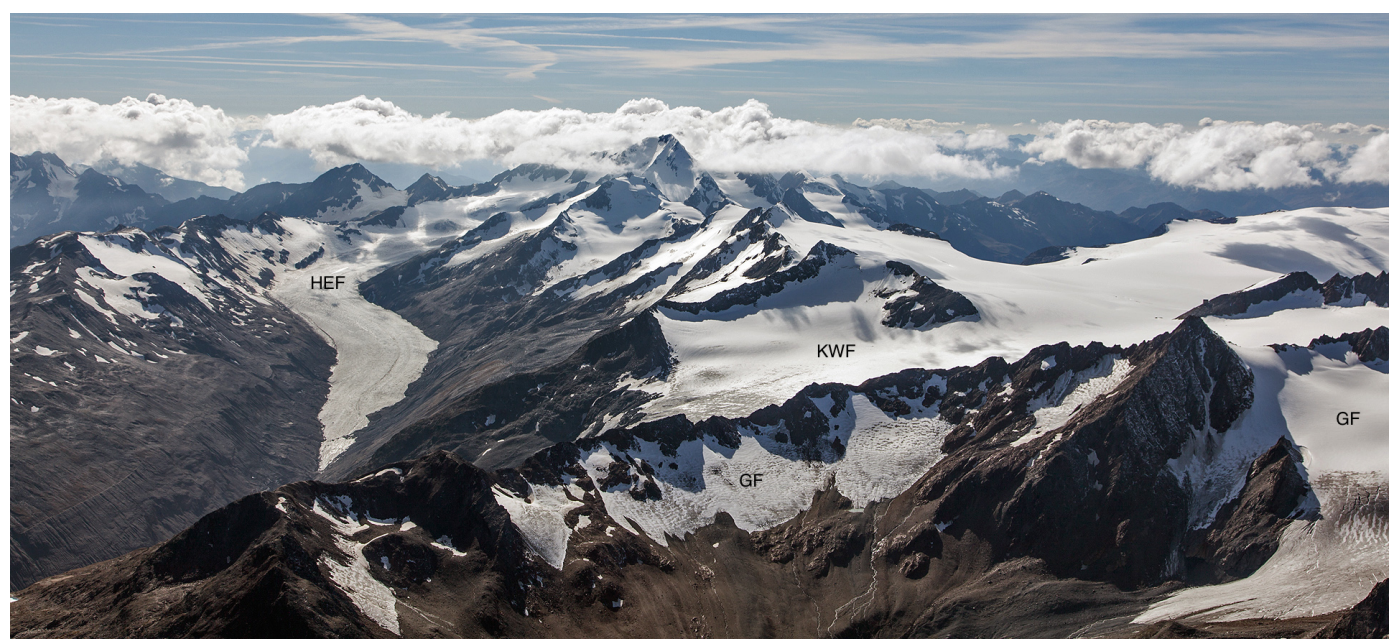

Figure 3. State of Hintereisferner (HEF), Kesselwandferner (KWF) and Guslarferner (GF) on 28 September 2014. Aerial photo by Christoph Mayer, view to the south.

latitudes and longitudes of their bounds. The data described in the present publication have been collected by several institutions operationally measuring cryospheric, atmospheric and hydrological variables along with their changes in the framework of their monitoring programs in the Rofental in the Ötztal Alps, Austria. The institutions involved are the University of Innsbruck with the Department of Atmospheric and Cryospheric Sciences (formerly Institute of Meteorology and Geophysics, http://acinn.uibk.ac.at), the Department of Geography (http://uibk.ac.at/geographie), the Bavarian Academy of Sciences and Humanities in Munich (geo.badw.de) and the Hydrographic Service of Tyrol in Innsbruck (http://tirol.gv.at/umwelt/wasser/wasserkreislauf) which is a section of the Federal Ministry of Agriculture, Forestry, Environment and Water Management (BMLFUW, http://bmlfuw.gv.at).

In this paper, we document the available data from the Rofental area. It is structured in (i) glaciological data, i.e., recordings of glacier volume and geometry changes for HEF, KWF, VF and HJF; (ii) meteorological data as recorded by temporally installed or permanent AWSs; (iii) hydrological data characterizing the water balance of the respective glaciated (sub) catchment; and (iv) airborne and terrestrial laser scanning data. The link to the respective PANGAEA repository parent is https://doi.org/10.1594/PANGAEA.876120. This parent comprises all DOI links to download the data described. Nevertheless, the respective direct DOI links are explicitly referred to here as well.

The selection of data, documented here and available for download from PANGAEA, is only a portion of all the observations that have been collected. Countless documents, photographs, tables and analogue measuring tapes await digitization, and many older digital data still have to be processed and correctly documented. According to the purpose of the
INARCH special issue to which this paper belongs we have concentrated our efforts on providing (i) a mostly complete picture of the water balance components of the Rofental the mass balances of the observed glaciers being an important highlight of these - and (ii) the meteorological data to force a typical hydrological catchment model. Particular attention is paid to the glaciological, meteorological and hydrological processes in the complex Alpine topography and their spatiotemporal variations in the valley.

\section{The Rofental - site description}

The Rofental $\left(98.1 \mathrm{~km}^{2}\right.$, Fig. 4) is a glaciated headwater catchment in the central eastern Alps, namely in the upper Ötztal Alps (Tyrol, Austria): as of 2008 approximately onethird of its area is ice-covered (Müller et al., 2009). The valley floor is a narrow discontinuous riparian zone typically less than $100 \mathrm{~m}$ in width. The Rofental stretches from $1891 \mathrm{~m}$ a.s.l. at the gauge at Vent, the lowest point of the catchment, to $3772 \mathrm{~m}$ a.s.l. at the summit of Wildspitze, the highest summit of Tyrol. The average slope is $25^{\circ}$ and the average elevation is $2930 \mathrm{~m}$ a.s.l.. The Rofenache is a tributary to the Venter Ache, Ötztaler Ache and the Inn and as such contributes to the Danube system (i.e., the Black Sea). The river gauge at Vent $\left(1891 \mathrm{~m}\right.$ a.s.l., $\left.46.85694^{\circ} \mathrm{N}, 10.82361^{\circ} \mathrm{E}\right)$ has been operated continuously from the Hydrographic Service of Tyrol since 1967 . The characteristic water discharges $\left(\mathrm{m}^{3} \mathrm{~s}^{-1}, 1971-2013\right)$ are $\mathrm{NQ}=0.09$ (lowest discharge), $\mathrm{MQ}=4.6$ (mean discharge) and $\mathrm{HQ}=109$ (highest discharge); further characteristic data are published as annual review in the "Hydrographisches Jahrbuch von Österreich" (e.g., BMLFUW, 2011; available at: http://bmlfuw. gv.at,data-downloadatehyd.gv.at). The runoff regime of the Rofenache has not been modified by any measures of hydropower generation and is dominated by the melt of snow 


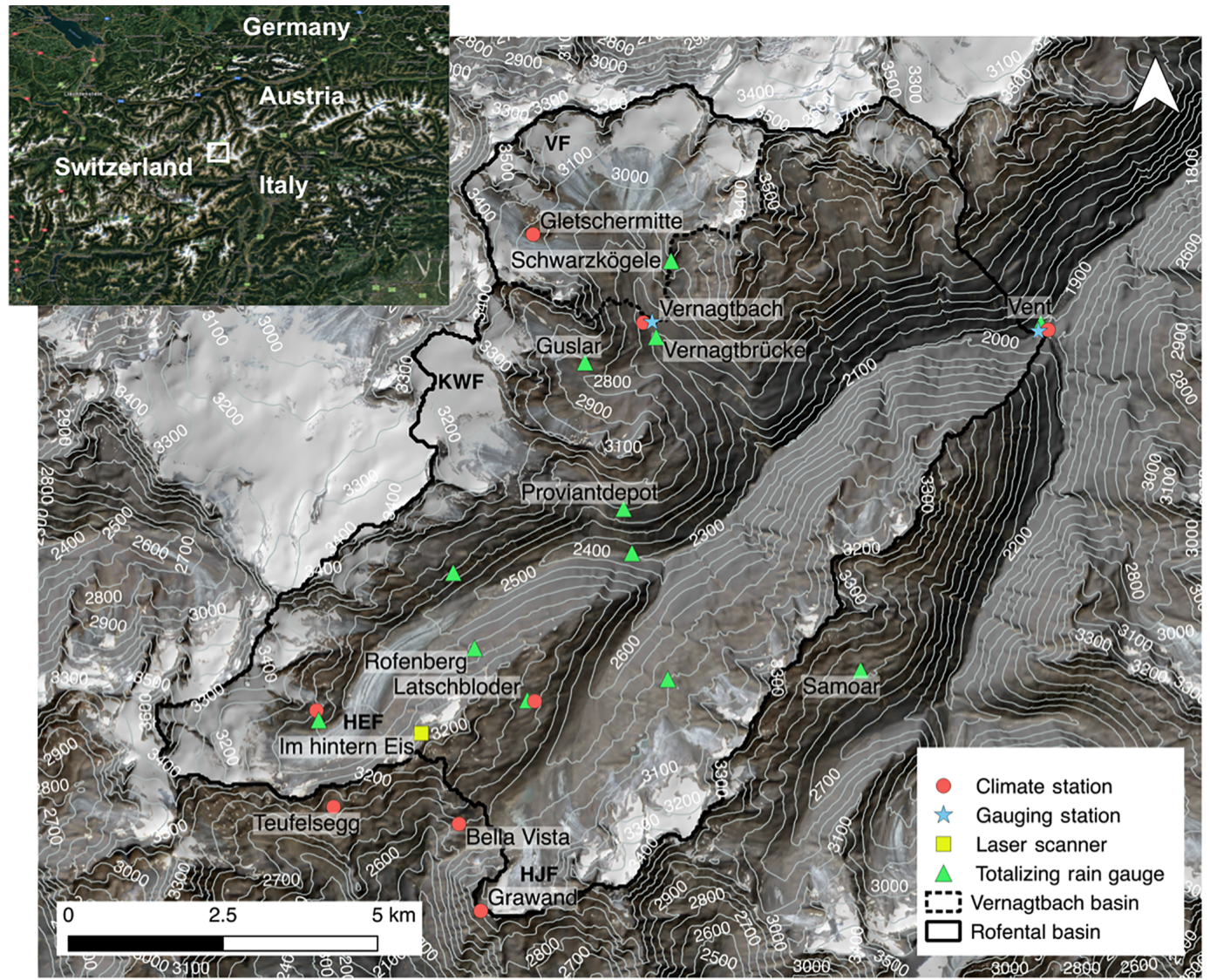

Figure 4. The Rofenache $\left(98.1 \mathrm{~km}^{2}\right)$ and Vernagtbach $\left(11.44 \mathrm{~km}^{2}\right)$ catchments with permanent meteorological stations and the runoff gauges. Background satellite image of the top left inset from maps.google.com, copyrights by Google (2009) and TerraMetrics (2017).

and ice during spring and summer, respectively. The early melt-season onset is typically in April. The gauge at Vernagtbach (2635 ma.s.l.) has been operationally maintained by the Bavarian Academy of Sciences and Humanities since 1973 and is the highest streamflow recording site in Austria with measurements also documented at http://ehyd.gv.at (see above) since 2003. The Vernagtbach catchment stretches from $2635 \mathrm{~m}$ a.s.l. at the gauge to $3635 \mathrm{~m}$ a.s.l. at the summit of Hinterer Brochkogel. According to the glacier inventory of 2006 (https://doi.org/10.1594/PANGAEA.844985), the ice coverage of the Vernagtbach at that time was $71 \%$. The current rapid decrease of the glaciated area in the Rofental is documented in the WGMS database (http://wgms.ch).

The climate of the Rofental is characterized as an inner Alpine dry type (Fig. 5). The mean annual temperature at the station in Vent $\left(1900 \mathrm{~m}\right.$ a.s.l., $\left.46.85833^{\circ} \mathrm{N}, 10.91250^{\circ} \mathrm{E}\right)$ is $2.5^{\circ} \mathrm{C}$, and total annual precipitation varies between $797 \mathrm{~mm}$ in Vent (1982-2003, Kuhn et al., 2006) and $>1500 \mathrm{~mm}$ in the higher altitudes around $3000 \mathrm{~m}$ a.s.l., confirmed by the recordings at the various totalisators (see Sect. 3.2.3, Table 4). In these higher regions, seasonal snow cover lasts from October until the end of June. Figure 5 shows temper- atures and precipitation of the station at Vent at $1900 \mathrm{~m}$ a.s.l. for the period 1969-2006.

The geological bedrock in the Rofental area mainly consists of biotite-plagioclase, biotite and muscovite gneisses, variable mica schists, and gneissic schists of the Austroalpine Ötztal nappe (Kreuss, 2012; Moser, 2012). Subordinate lithologies are quartzites and graphite schists. Granitic gneisses, amphibolites and diabase occur as layers ranging from a few meters to a few hundred meters thick within the metasedimentary sequence. Land cover in the Rofental is dominated by mountain pastures and coniferous forests in the lower areas, but these only cover little of the area (source: "Land Tirol", http://data.tirol.gv.at). Permafrost is likely to occur at north-facing slopes at higher altitudes (Klug et al., 2016).

Infrastructure in the valley is very good for monitoring instrumentation and fieldwork. A research station at HEF (built in 1966 in 3026 ma.s.l.) and one at Vernagtbach (built in 1973 in 2637 ma.s.l.) serve as logistic bases for fieldwork on the two glaciers. Several mountain huts are located in the Rofental, namely the "Vernagthütte/Würzburger Haus" (2755 m a.s.1.), the "Hochjoch-Hospiz" (2413 m a.s.l.), the "Brandenburger Haus" (3277 ma.s.l.) and close by the 


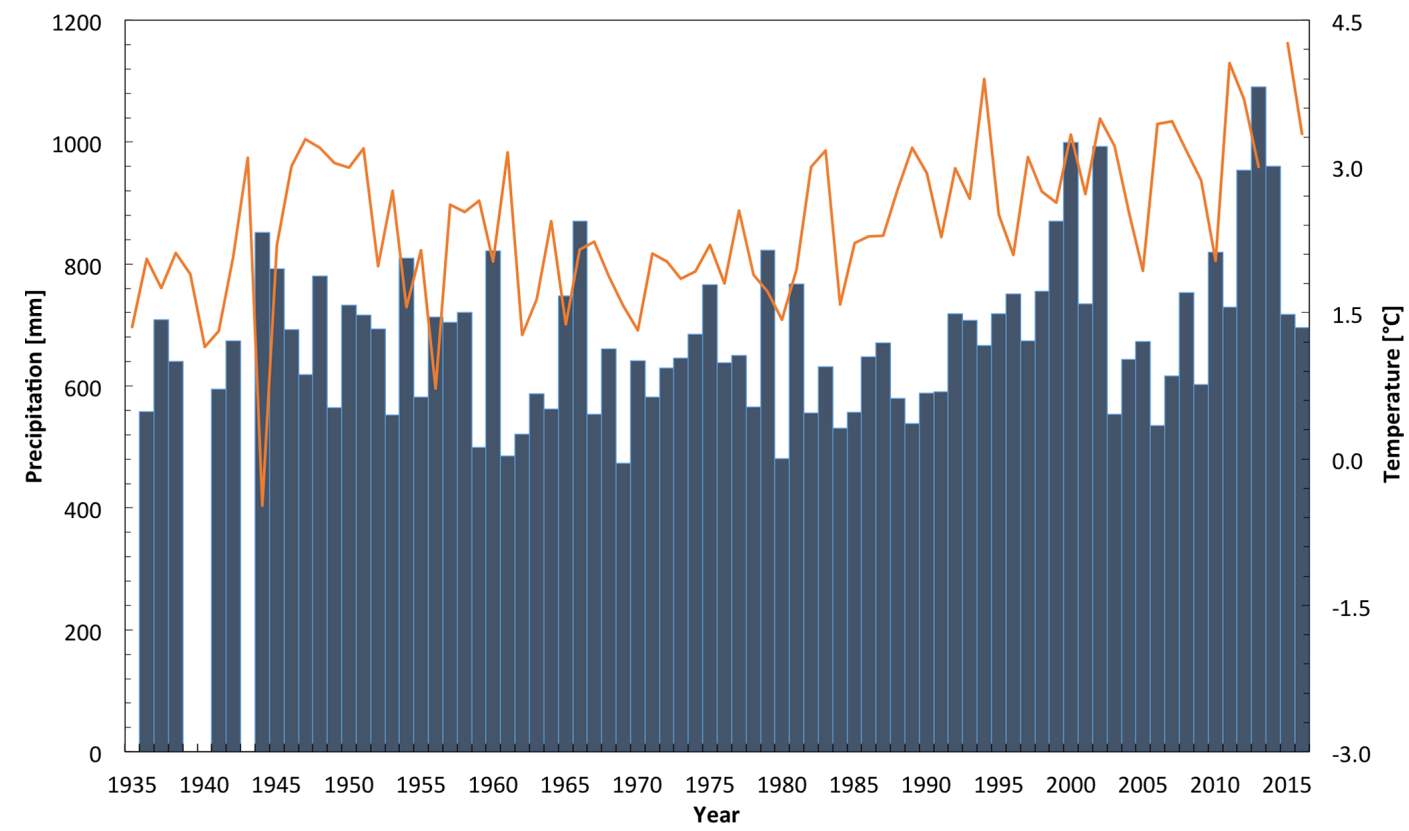

Figure 5. Annual precipitation sums (blue bars) and mean annual temperatures (orange line) 1935-2016 for the valley station "Vent" (1900 m a.s.1.). Data from PANGAEA (1935-2011: https://doi.org/10.1594/PANGAEA.806582 and 2012-2016: https://doi.org/10.1594/ PANGAEA.876595).

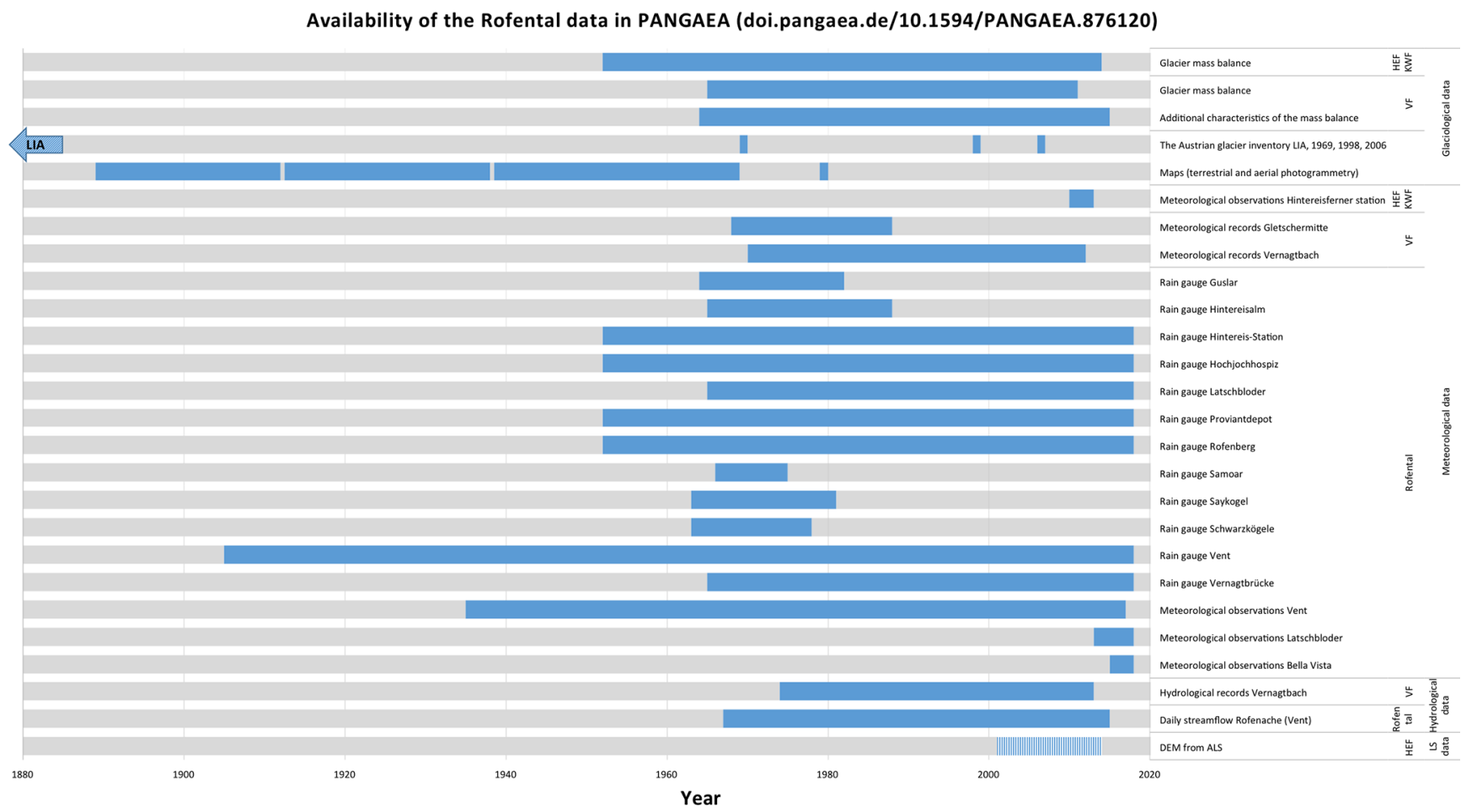

Figure 6. Available data time series for the Rofental in PANGAEA, structured in glaciological data, meteorological data, hydrological data and laser scanning data. LIA $=$ little ice age.

Austrian-Italian borderline at the Hochjoch the "Schöne Aussicht" (also known as "Bella Vista", 2845 m a.s.1.), within the Schnalstal glacier ski resort (http://schnalstal.com/en/ glacier). The "Rofenhöfe" (2014 m a.s.1.), the highest permanently settled mountain farm in Austria, is well situated as base camp in the lower valley floor. 
(a)

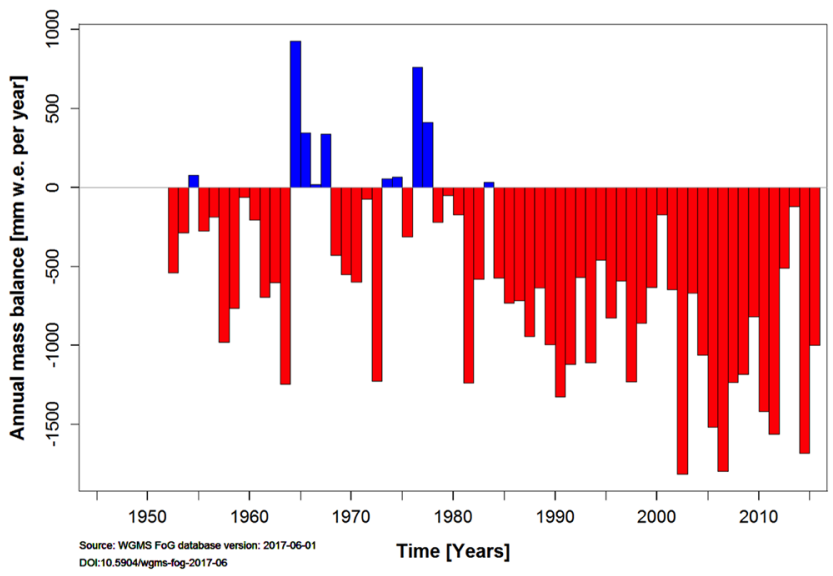

(c)

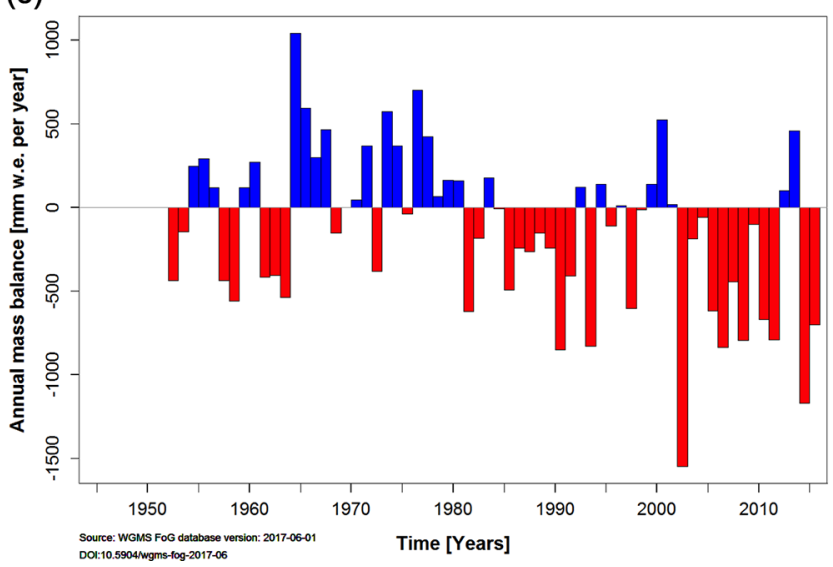

(b)

VERNAGT F., AT (WGMS_ID: 489)

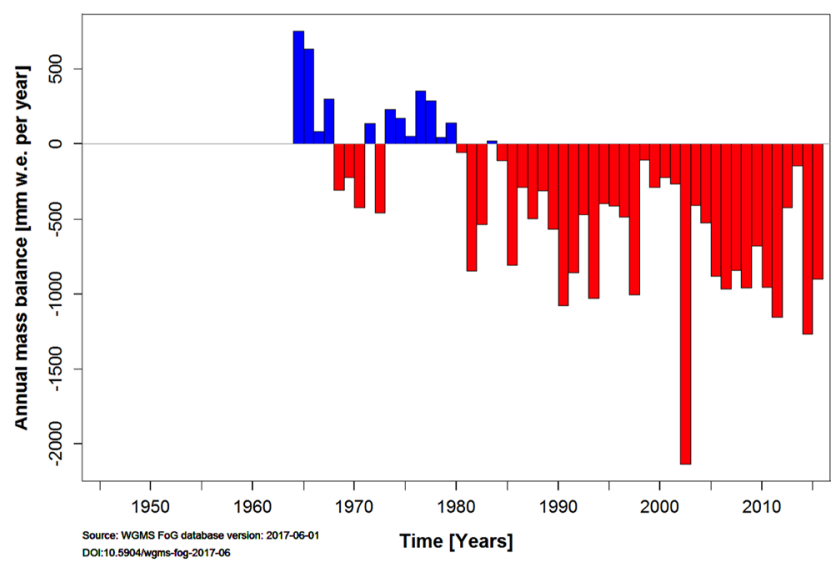

HOCHJOCH F., AT (WGMS_ID: 492)

(d)

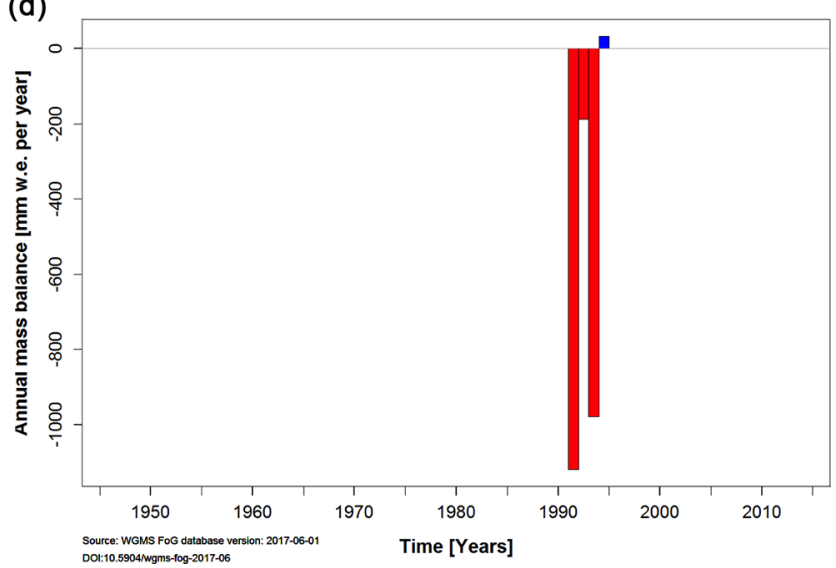

Figure 7. Annual mass balances for Hintereisferner (a), Vernagtferner (b), Kesselwandferner (c) and Hochjochferner (d) after the glaciological method using stake readings and snow pit data. From WGMS (http://wgms.ch, https://doi.org/10.5904/wgms-fog-2017-06).

\section{The data}

In the following chapter the Rofental data are presented in the chronological order in which it has been recorded (Fig. 6). First, we describe the long time series of glaciological data (Sect. 3.1). HEF and KWF are monitored by the University of Innsbruck (Austria), whereas VF is monitored by the Bavarian Academy of Sciences and Humanities (Munich, Germany). Next, we describe the meteorological data, again structured by location, i.e., in the order HEF and KWF, VF, and then the valley area (Sect. 3.2). Following that, we describe the hydrological data, firstly in the HEF and KWF catchments, then the VF catchment, and finally, the Rofental as a whole (Sect. 3.3). In the last section (Sect. 3.4), the airborne and terrestrial laser scanning data, which serves glaciological, geomorphological and wider modeling purposes, is described.

\subsection{Glaciological data}

All glaciers in the Rofental are included in the three Austrian glacier inventories carried out in 1969, 1998 and 2006 (http://glaziologie.at/gletscherinventar.html) and also in the inventory of reconstructed glaciers at the time of the LIA (Kuhn et al., 1999, 2009, 2012; Lambrecht and Kuhn, 2007; Fischer et al., 2015), allowing detailed studies of the deglaciation in the catchments. The parent directory on PANGAEA for the Austrian glacier inventory is https://doi.org/10.5194/tc-9-753-2015, including the LIA maximum (https://doi.org/10.1594/PANGAEA.844987), and the years 1969 (https://doi.org/10.1594/PANGAEA.844983), 1998 (https://doi.org/10.1594/PANGAEA.844984) and 2006 (https://doi.org/10.1594/PANGAEA.844985). Annual reports of the variations of HEF (ID 491, since 1952), KWF (ID 507, since 1966), VF (ID 489, since 1965) and HJF (ID 492, 1991-1995) are provided to the World Glacier Monitoring Service (WGMS; http://wgms.ch) (Fig. 7). 


\subsubsection{Hintereisferner and Kesselwandferner}

Changes in the areas of HEF and KWF have been documented on the basis of maps, aerial photos, and more recently satellite and airborne derived digital elevation models (DEMs) since the early 19th century (Lambrecht and Kuhn, 2007; see also the introduction). The traditional glaciological method of determining glacier-wide mass balance involves spatial extrapolation of local measurements of ablation and accumulation to provide values of the climatic mass balance, encompassing changes at the glacier surface and in the near subsurface (Cogley et al., 2011). Uncertainties in the methods are discussed in Zemp et al. (2013). Since 1952, a network of measurement stakes and pits was continuously maintained at HEF to directly measure the mass balance of the glacier (Hoinkes, 1970). Summer and winter mass balances have been measured separately. Interpretation of the surface mass changes of HEF is supported by the availability of daily images from an automatic camera which views the upper part of the glacier to below the ELA, providing useful information on the distribution of snow cover and the pattern of snow melt over the glacier surface. From 1952-2013 the mass balance of KWF has also been recorded, but with a much smaller number of observations and the assumption that the spatial distribution of the mass balance is analogous to the one of the adjacent HEF. Since summer 2013 a full network of observations is also undertaken and maintained at KWF. The mass balance values of HEF and KWF are available at WGMS (ID 491 and 507, since 1952 and 1966; see Fig. 7) and are also archived in the PANGAEA database (https://doi.org/10.1594/PANGAEA.803830, https://doi.org/10.1594/PANGAEA.803829,

https://doi.org/10.1594/PANGAEA.818898

https://doi.org/0.1594/PANGAEA.818757).

and

Geodetic determinations of glacier mass balance involve determining the volume change of the whole glacier body, encompassing englacial and basal volume changes. The volume change must then be converted into a mass change which is complicated in the case of a rapidly changing glacier whose surface type can change significantly over the monitoring interval. Apart from the geodetic mass balances on the basis of the glacier inventories, airborne laser scanning images are available for HEF since 2001 (see Sect. 3.4). From these, a time series of geodetic mass balances was derived for 2001-2002 to 2010-2011 (Fig. 8). This method allows for pixel-by-pixel correction of method-inherent discrepancies in the classical glaciological method (Klug et al., 2017).

\subsubsection{Vernagtferner}

Glaciological mass balance measurements for VF have been available since 1965 (Mayer et al., 2013a). Since the beginning, annual and winter balance was measured separately in order to discriminate ice melt and snow accumulation. The

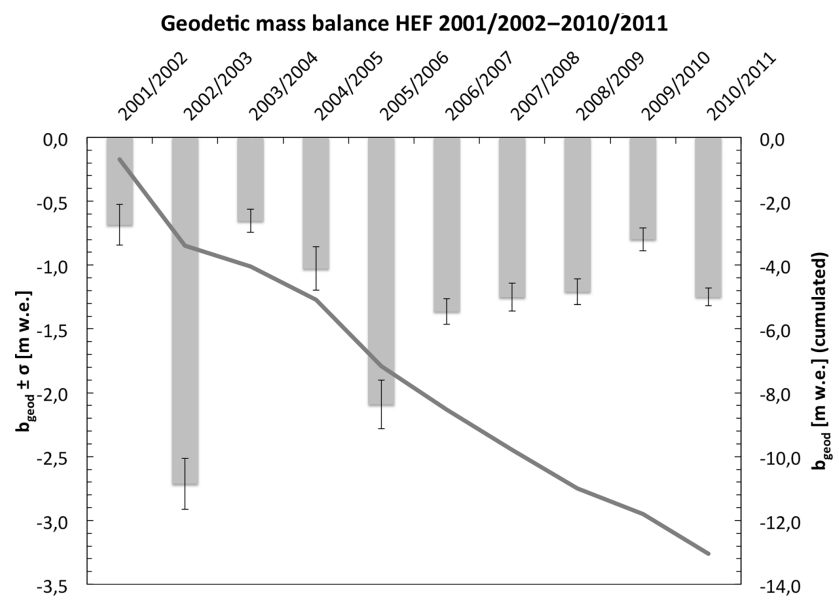

Figure 8. Available geodetic mass balances $b_{\text {geod }} \pm \sigma$ [m w.e.] for Hintereisferner from 2001-2011 and the cumulated balance 20012011 ( $b_{\text {geod }}$ cumulated) as derived from airborne laser scanning measurements (Klug et al., 2017; see also Sect. 3.4).

mass balance values are available at WGMS (ID 489, since 1965; see Fig. 7) and are also archived in the PANGAEA database (https://doi.org/10.1594/PANGAEA.853832). The measurements are based on stake readings and snow pits for the annual balance, and snow depth probing and snow pits for the winter balance. The point data are then interpolated on the temporally closest map of the glacier. A summary of the mass balance series for $\mathrm{VF}$ is given in Fig. 9. Additional characteristics of the Vernagtferner mass balance for the period 1964-2014 are available at https://doi.org/10.1594/PANGAEA.854639.

In 1976, an automatic analogue camera has been installed on "Schwarzkögele" (3075 ma.s.1., $46.86575^{\circ} \mathrm{N}$, $10.83245^{\circ} \mathrm{E}$ ), capturing one picture of VF and its surrounding per day during the ablation period. Since 2010, three digital pictures per day are produced throughout the year (Weber, 2013). A time series of maps is available for VF since 1889, derived from terrestrial and aerial photogrammetry, aerial laser scanning and optical line scanner images; these maps are used to determine area and volume changes of the glacier for longer periods (Table 1 and Mayer et al., 2013b).

\subsection{Meteorological data}

Due to its complex topography, the Rofental is characterized by steep environmental gradients and large spatiotemporal variations of meteorological conditions. An ongoing effort has been undertaken to supplement data available from the lower regions with additional AWS installations in the higher elevations. As of 2017, the Rofental offers a comprehensive pool of valuable observations and model forcing data for mountain catchment hydrology research (Fig. 4; see also the introduction in Sect. 1). 


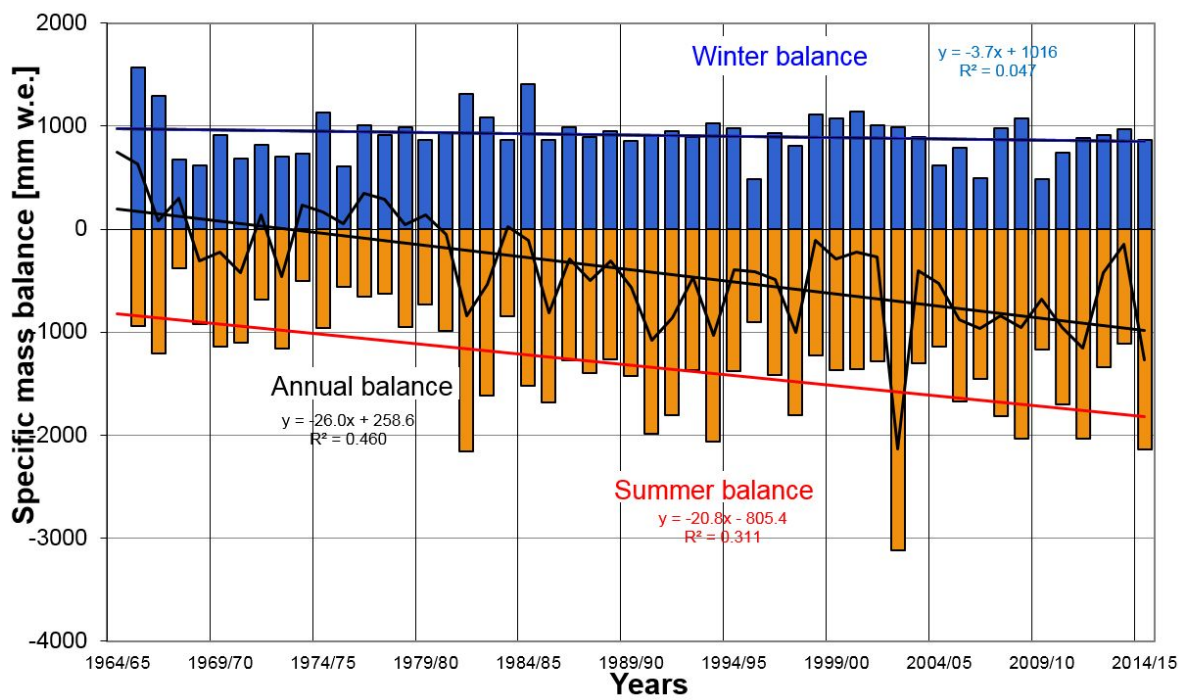

Figure 9. Graphical summary of the seasonal and annual mass balances of Vernagtferner from 1965 until 2014. The vertical bars represent seasonal values and the black line annual values.

Table 1. Available maps of Vernagtferner.

\begin{tabular}{|c|c|c|c|c|}
\hline Year & Type & Area $\left(\mathrm{km}^{2}\right)$ & Volume change $\left(\mathrm{km}^{3}\right)$ & DOI \\
\hline 1889 & Terrestrial photogrammetry & 11549 & & https://doi.org/10.1594/PANGAEA.834873 \\
\hline 1912 & Terrestrial photogrammetry & 11509 & -2.137 & https://doi.org/10.1594/PANGAEA.834873 \\
\hline 1938 & Terrestrial photogrammetry & 10410 & -4.382 & https://doi.org/10.1594/PANGAEA.834873 \\
\hline 1954 & - & 9474 & -4.543 & * T \\
\hline 1969 & Aerial photogrammetry & 9466 & 0.634 & https://doi.org/10.1594/PANGAEA.834873 \\
\hline 1979 & Aerial photogrammetry & 9397 & 1.840 & https://doi.org/10.1594/PANGAEA.771301 \\
\hline 1990 & Aerial photogrammetry & 8982 & -4.931 & $*$ \\
\hline 1999 & Aerial photogrammetry & 8680 & -7.888 & $*$ \\
\hline 2003 & Aerial photogrammetry & 8430 & -3.355 & * \\
\hline 2006 & Optical line scanner & 8173 & -8.970 & $*$ \\
\hline 2009 & Optical line scanner & 7748 & -8.403 & * \\
\hline
\end{tabular}

* Data set will be uploaded to PANGAEA as soon as it is processed, quality checked and documented.

For all stations, the height of the sensors above ground is at least $1.5 \mathrm{~m}$; in winter, the distance between the snow surface and the sensors can become much smaller, and in extreme snow-rich periods the instruments even can become completely snow-covered. Such periods can be recognized in the data by typical recordings of zero wind speed and increasing dampening of the other meteorological variables.

\subsubsection{Hintereisferner and Kesselwandferner}

The first meteorological observations at HEF and its surrounding began in 1968 and are documented in Kuhn et al. (1979). Short term projects, dedicated to measuring the surface mass balance of snow and ice on the glacier involved temporary installations of AWSs on the glacier (e.g., Siogas, 1977a; Harding et al., 1989; Obleitner, 1994). Since 2010, automatic meteorological measurements have been carried out at station "Hintereisferner" (3026 m a.s.1., $46.79867^{\circ} \mathrm{N}$, $10.76042^{\circ} \mathrm{E}$ ) (Fig. 10). The installation as of 2017 is detailed in Table 2.

Since 2014 an AWS has been seasonally operated on the glacier terminus, providing the meteorological data for surface energy balance assessments of the ice surface, complemented by surface height change observations with a sonic ranger.

From summer 2017, the permanent meteorological measurements at Hintereisferner will be complemented by recordings of the sensors on a $6 \mathrm{~m}$ high tower that has been equipped for detailed turbulent flux measurements (see Sect. 3.2.3). This new station is situated close to the permanent terrestrial laser scanner on Im hintern Eis (3244 m a.s.l., $46.79586^{\circ} \mathrm{N}, 10.78277^{\circ} \mathrm{E}$; see Sect. 3.4.2). 


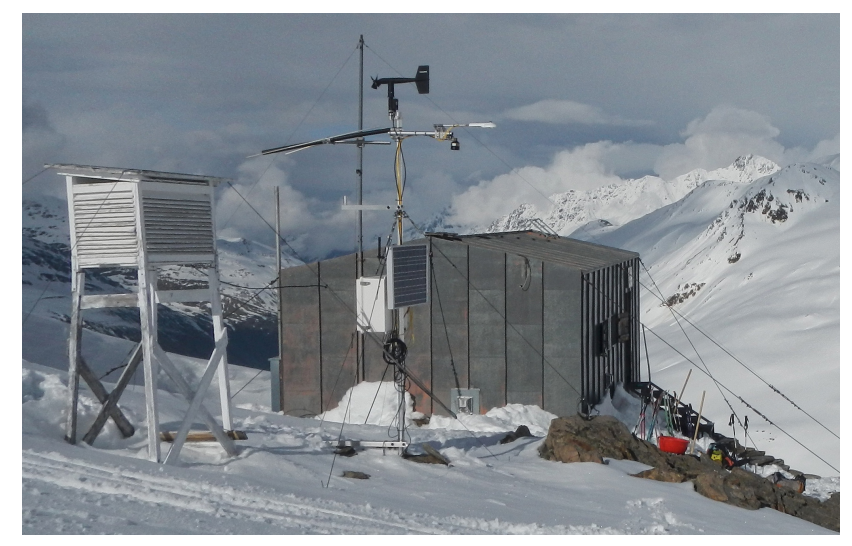

Figure 10. The Hintereisferner AWS and research station in June 2013 (3026 $\mathrm{m}$ a.s.1., $46.79867^{\circ} \mathrm{N}, 10.76042^{\circ} \mathrm{E}$ ), view to the northeast. Photo by Christian Wild.

For KWF, only the meteorological observations on the glacier from 1958 by Ambach and Hoinkes (1963) are documented.

\subsubsection{Vernagtferner}

After the start of the glacier monitoring program by the Bavarian Academy of Sciences and Humanities, meteorological observations were initiated at the glacier forefield with the installation of a precipitation gauge in 1970 . With the completion of the gauging station "Vernagtbach" $\left(2635 \mathrm{~m}\right.$ a.s.l., $46.85675^{\circ} \mathrm{N}, 10.82886^{\circ} \mathrm{E}$; see Sect. 3.3.2), additional meteorological parameters have been observed since 1974 at the Vernagtbach climate station close by $\left(2640 \mathrm{~m}\right.$ a.s.l., $\left.46.85663^{\circ} \mathrm{N}, 10.82857^{\circ} \mathrm{E}\right)$ (https://doi.org/10.1594/PANGAEA.775113). In 1975 hourly measurements of air temperature, relative humidity, air pressure, wind speed and direction were started. The same instruments were installed at the station "Gletschermitte" (3078 ma.s.1.), situated on a rock outcrop in the western part of the glacier at $46.86894^{\circ} \mathrm{N}, 10.80299^{\circ} \mathrm{E}$, where hourly meteorological observations were collected during the summer months from 1968 until 1987 (with a varying beginning and end from year to year). The observed parameters were air temperature, relative humidity, wind speed and direction, and precipitation (https://doi.org/10.1594/PANGAEA.832562). Radiation sensors were installed at Vernagtbach in 1976. However, especially during winter, data gaps frequently occurred. The situation was considerably improved by installation of a first digital data logger in 1984. Since then, all-year data records are available from the Vernagtbach station (Escher-Vetter and Siebers, 2013). The meteorological observations were revised in 2002 with the installation of a modern AWS (Fig. 11), and since then all data are automatically transferred to the Bavarian Academy of Sciences and Humanities via GSM and a satellite network. In August 2010, the

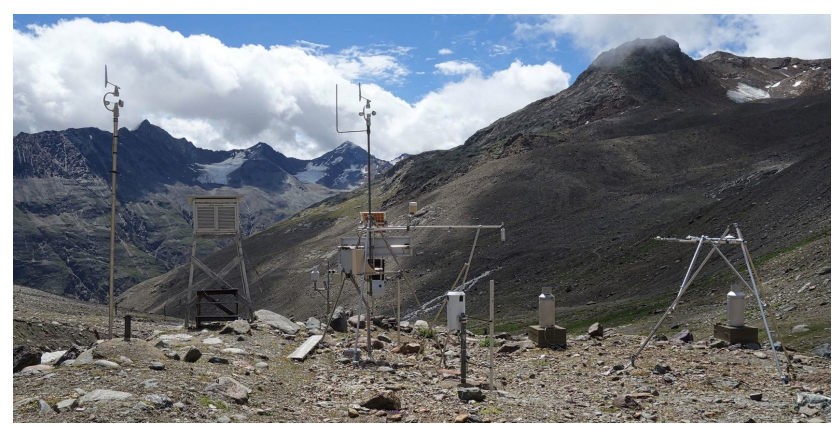

Figure 11. The Vernagtbach AWS in July 2017 (2640 ma.s.l., $46.85663^{\circ} \mathrm{N}, 10.82857^{\circ} \mathrm{E}$ ), view to the southeast. Photo by Ludwig Braun.

Hydrographic Service of Tyrol extended the installation with a separate temperature sensor and an unheated Pluvio 2 pluviometer $\left(2630 \mathrm{~m}\right.$ a.s.l., $\left.46.85667^{\circ} \mathrm{N}, 10.82861^{\circ} \mathrm{E}\right)$. Details about the most recent sensor configurations are given in Table 3.

On "Schwarzkögele" (3075 m a.s.l., $46.86575^{\circ} \mathrm{N}$, $10.83245^{\circ} \mathrm{E}$ ), a summit in the vicinity of $\mathrm{VF}$, an autonomous climate station has been in operation since 1976 (Braun et al., 2013). Data recorded there comprise air temperature, relative humidity, global radiation, wind speed and direction as well as precipitation. After digitization these measurements will be made available in PANGAEA. Experiments and special investigations in the catchment of VF are listed in Escher-Vetter and Siebers (2013); since 2003, the meteorological observations have been extended to the ice surface of the glacier itself. Whereas in the first years these data have gaps (mainly in winter), they are mostly continuous since 2011.

\subsubsection{Rofental apart from the glaciers}

In the Rofental several totalizing rain gauges have are used to collect precipitation data, the first of which was installed in 1905 (see Fig. 6). The totalizing rain gauges are operated by the Department of Atmospheric and Cryospheric Sciences of the University of Innsbruck with financial support by the Hydrographic Service of Tyrol. These totalizing rain gauges provide a valuable picture of the historical evolution and temporal variability of precipitation, and they support the development of precipitation fields derived from interpolation of the recordings (Hoinkes and Steinacker, 1975), which is particularly important for distributed modeling exercises. Evaporation and freezing of the devices is inhibited by annual additions of oil and salt to the gauge reservoir. Readings of totals are undertaken every 2 months in summer with a 4-month break in winter. These totals are then redistributed to monthly values using the recordings of the weighing rain gauge in Vent. Altitude, geographical location and the period 


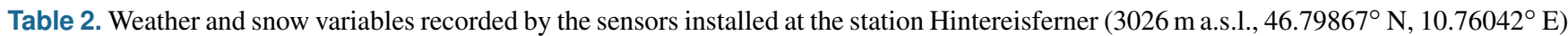
in 2010, 2011 and 2012. Accuracy according to technical data sheets of the manufacturers. Original temporal resolution of the data records is $10 \mathrm{~min}$.

\begin{tabular}{|c|c|c|c|c|}
\hline Variable & Sensor & Period of operation & Accuracy & Unit \\
\hline Air temperature & Vaisala HMP45AC & Since October 2010-present & $\pm 0.13^{\circ} \mathrm{C}$ & ${ }^{\circ} \mathrm{C}$ \\
\hline Relative humidity & Vaisala HMP45AC & Since October 2010-present & $\begin{array}{l} \pm 2 \% \mathrm{RH} \text { for } 0-90 \% \mathrm{RH} \\
\pm 3 \% \mathrm{RH} \text { for } 90-100 \% \mathrm{RH}\end{array}$ & $\%$ \\
\hline Wind speed and direction & Young Wind Monitor & Since October 2010-present & $0.5-1 \mathrm{~m} \mathrm{~s}^{-1} ; \pm 3^{\circ}$ & $\mathrm{ms}^{-1}$ and $^{\circ}$ \\
\hline $\begin{array}{l}\text { Shortwave and longwave } \\
\text { radiative fluxes }\end{array}$ & Kipp \& Zonen CNR 4 & Since October 2010-present & $\begin{array}{l} \pm 10 \% \text { (outgoing) } \\
<10 \% \text { (incoming) }\end{array}$ & $\mathrm{W} \mathrm{m}^{-2}$ \\
\hline Atmospheric pressure & Setra CS 100 & Since October 2010-present & $\pm 0.1 \mathrm{hPa}$ & $\mathrm{hPa}$ \\
\hline Soil and snow temperature & BetaTherm 100K6A & Since October 2010-present & $\pm 0.3^{\circ} \mathrm{C}$ & ${ }^{\circ} \mathrm{C}$ \\
\hline Snow depth & Campbell SR50A & Since October 2010-present & $1 \mathrm{~cm}$ (or $0.4 \%$ of distance) & $\mathrm{cm}$ \\
\hline
\end{tabular}

Data 2010: https://doi.org/10.1594/PANGAEA.809091; 2011: https://doi.org/10.1594/PANGAEA.809094; 2012: https://doi.org/10.1594/PANGAEA.809095.

Table 3. Sensors and sampling intervals of the AWS Vernagtbach $\left(2640 \mathrm{~m} \text { a.s.1., } 46.85663^{\circ} \mathrm{N}, 10.82857^{\circ} \mathrm{E}\right)^{*}$.

\begin{tabular}{|c|c|c|c|c|}
\hline Variable & Sensor & Period of operation & Interval & Unit \\
\hline Air temperature (ventilated) & Thies PT-100 & Since 2002 & $5 \mathrm{~s} 10 \mathrm{~min}^{-1}$ & ${ }^{\circ} \mathrm{C}$ \\
\hline Air temperature (unventilated) & PT-100 & Since 2002 & $5 \mathrm{~s} 10 \min ^{-1}$ & ${ }^{\circ} \mathrm{C}$ \\
\hline Relative humidity & Thies hair hygrometer & Since 2002 & $20 \mathrm{~s} 10 \mathrm{~min}^{-1}$ & $\%$ \\
\hline Wind speed & Thies cup anemometer & Since 2002 & $5 \mathrm{~s} 10 \mathrm{~min}^{-1}$ & $\mathrm{~ms}^{-1}$ \\
\hline Wind direction & Thies wind vane & Since 2002 & $5 \mathrm{~s} 10 \min ^{-1}$ & $\circ$ \\
\hline Shortwave downward radiation & Kipp \& Zonen CM7B unventilated & Since 2002 & $5 \mathrm{~s} 10 \mathrm{~min}^{-1}$ & $\mathrm{~W} \mathrm{~m}^{-2}$ \\
\hline Shortwave upward radiation & Kipp \& Zonen CM7B unventilated & Since 2002 & $5 \mathrm{~s} 10 \mathrm{~min}^{-1}$ & $\mathrm{~W} \mathrm{~m}^{-2}$ \\
\hline Longwave downward radiation & Schenk Pyradiometer 8111 unventilated & Since 2002 (summer only) & $5 \mathrm{~s} 10 \mathrm{~min}^{-1}$ & $\mathrm{~W} \mathrm{~m}^{-2}$ \\
\hline Longwave upward radiation & Schenk Pyradiometer 8111 unventilated & Since 2002 (summer only) & $5 \mathrm{~s} 10 \min ^{-1}$ & $\mathrm{~W} \mathrm{~m}^{-2}$ \\
\hline Precipitation sum & Belfort weighing gauge & Since 2002 & $5 \mathrm{~s} 10 \mathrm{~min}^{-1}$ & $\mathrm{~mm}$ \\
\hline Precipitation difference & Gertsch tipping bucket, unheated & Since 2002 & Sum in $10 \mathrm{~min}$ & $\mathrm{~mm}$ \\
\hline Air pressure & Druck RPT 410 & Since 2002 & $20 \mathrm{~s} 10 \mathrm{~min}^{-1}$ & $\mathrm{hPa}$ \\
\hline Snow depth & Campbell SR50 & Since 2002 & $120 \mathrm{~s} 10 \mathrm{~min}^{-1}$ & $\mathrm{~mm}$ \\
\hline
\end{tabular}

* Further technical details can be found in Escher-Vetter and Siebers (2012). The additional temperature and rainfall recordings of the Hydrographic Service of Tyrol have been separately available since August 2010, visualized online at http://apps.tirol.gv.at/hydro/\#/Niederschlag/?station=197075; data upon request.

of operation of these totalizing rain gauges are given in Table 4 .

Meteorological observations have been made in close proximity to the village of Vent since 1934 (Lauffer, 1966; Siogas, 1977b). This long-term station provides a valuable reference for shorter series of meteorological observations and also the lower boundary conditions on the likely variation of meteorological variables with elevation across the catchment. Data are available for 19352011 at https://doi.org/10.1594/PANGAEA.806582, and for 2012-2016 at https://doi.org/10.1594/PANGAEA.876595. In September 2015 the weather station installation was updated and the position changed by a horizontal displacement of $102 \mathrm{~m}$ (new position: $1907 \mathrm{~m}$ a.s.l., $46.85745^{\circ} \mathrm{N}$, $\left.10.91288^{\circ} \mathrm{E}\right)$. The recordings of this station comprise the meteorological variables air temperature, relative humidity, wind speed and direction (since February 2016), and atmospheric pressure (since September 2016; same instruments and specifications as for station Hintereisferner, Table 2). Precipitation is recorded with a heated Ott Pluvio 2 in millimeters per hour with an accuracy of $0.1 \mathrm{~mm} \mathrm{~h}^{-1}$.

In the uppermost parts of the Hochjoch valley, two AWSs have been more recently brought into operation: "Latschbloder" (2919 m a.s.1., 46.80106 $\left.{ }^{\circ} \mathrm{N}, 10.80659^{\circ} \mathrm{E}\right)$, installed in September 2013, and Bella Vista (2805 m a.s.1., $46.78284^{\circ} \mathrm{N}, 10.79138^{\circ} \mathrm{E}$ ), installed in June 2015. The data of these two fully automatic stations complement the spatial picture of the meteorological variables in the upper zones of the Rofental. Both stations collect 10 min values of temperature, precipitation (unheated, but also recording by the type of precipitation), wind (mean and maximum speed and direction), relative humidity, radiative fluxes (incoming and outgoing short- and longwave) and air pressure (Table 5). The Latschbloder station is about $25 \mathrm{~m}$ from the totalizing rain gauge at the same site (see Table 4). Three continuous years of consistent records are available for 2014, 
Table 4. Totalizing rain gauges in the Rofental.

\begin{tabular}{|c|c|c|c|c|c|}
\hline Station & $\begin{array}{l}\text { Altitude } \\
\text { (m a.s.1.) }\end{array}$ & Lat. $\left({ }^{\circ} \mathrm{N}\right)$ & Long. $\left({ }^{\circ} \mathrm{E}\right)$ & Period of operation & DOI \\
\hline Vent & 1900 & 46.85766 & 10.91127 & 1905-present & https://doi.org/10.1594/PANGAEA.876532 \\
\hline Hochjochhospiz & 2360 & 46.82310 & 10.82616 & 1952-present & https://doi.org/10.1594/PANGAEA.876525 \\
\hline Vernagtbrücke & 2600 & 46.85461 & 10.82979 & 1965-present & https://doi.org/10.1594/PANGAEA.876533 \\
\hline Proviantdepot & 2737 & 46.82951 & 10.82407 & 1952-present & https://doi.org/10.1594/PANGAEA.876527 \\
\hline Rofenberg & 2827 & 46.80847 & 10.79344 & 1952-present & https://doi.org/10.1594/PANGAEA.876528 \\
\hline Latschbloder & 2910 & 46.80118 & 10.80561 & 1965-present & https://doi.org/10.1594/PANGAEA.876526 \\
\hline Hintereis station & 2964 & 46.79727 & 10.76096 & 1952-present & https://doi.org/10.1594/PANGAEA.876523 \\
\hline Saykogel & 2990 & 46.80491 & 10.83459 & $1963-1980$ & https://doi.org/10.1594/PANGAEA.876529 \\
\hline Schwarzkögele & 3075 & 46.86575 & 10.83245 & 1963-March 1977 & https://doi.org/10.1594/PANGAEA.876531 \\
\hline Guslar & 2920 & 46.85060 & 10.81489 & $\begin{array}{l}\text { October 1964- } \\
\text { September } 1981\end{array}$ & https://doi.org/10.1594/PANGAEA.876522 \\
\hline Samoar & 2650 & 46.80708 & 10.87539 & 1966-1974 & https://doi.org/10.1594/PANGAEA.876530 \\
\hline Hintereisalm & 2900 & 46.81941 & 10.78842 & 1965-September 1987 & https://doi.org/10.1594/PANGAEA.876524 \\
\hline
\end{tabular}

2015 and 2016 (mean annual temperature $-1.3,-1.5$ and $-2.2^{\circ} \mathrm{C}$ (WXT520), and annual precipitation: 1590, 1311 and $1118 \mathrm{~mm}$ (Pluvio 2 unheated)).

The weather station at Bella Vista includes a heated Ott Pluvio 2, supplied with main power from the "Schöne Aussicht-Hütte" approximately $90 \mathrm{~m}$ away. This site also includes fuller snow instrumentation (Table 6) to measure: snow water equivalent (by means of a snow pillow), snow depth (by means of an ultrasonic ranger) and snow temperature profile (by means of a series of temperature sensors at different height levels). These snow sensors are still undergoing technical examination and development, and as yet no check for consistency has been undertaken (e.g., by using the data as input in a snow model as in Morin et al., 2012). In 2016, mean annual temperature at the station was $-0.4{ }^{\circ} \mathrm{C}$, and annual precipitation was $1605 \mathrm{~mm}$. The Bella Vista weather and snow monitoring station is one of the highest of its kind in the Alps. During summer 2017 an automatic camera that has the station in its field of view has been installed (Fig. 12).

In summer 2017 , a $6 \mathrm{~m}$ high tower close to the permanent terrestrial laser scanner on Im hintern Eis (3244 m a.s.l., $46.79586^{\circ} \mathrm{N}, 10.78277^{\circ} \mathrm{E}$; see Sect. 3.4.2) was equipped for detailed turbulent flux measurements with the following sensors: three Lufft Ventus 2-D Sonic wind sensors at 1.5, 3 and $6 \mathrm{~m}$ altitude; two ventilated Rotronic HC2-S3 temperaturehumidity sensors at 3 and $6 \mathrm{~m}$ altitude; a Campbell SR50 AH heated ultrasonic snow depth sensor in $1.5 \mathrm{~m}$ altitude; a Campbell Krypton hygrometer at $3 \mathrm{~m}$ altitude (only for specific campaigns); a Kipp \& Zonen CNR4 net radiometer at $1.5 \mathrm{~m}$ altitude; a Metek USA-1 3-D sonic turbulence sensor at $3 \mathrm{~m}$ altitude; and a Setra 278 barometric pressure sensor in the logger box. The data of these sensors will be made available in PANGAEA as soon as first tests have proven the installation to be reliable, and a time series of at least a year of data is available.

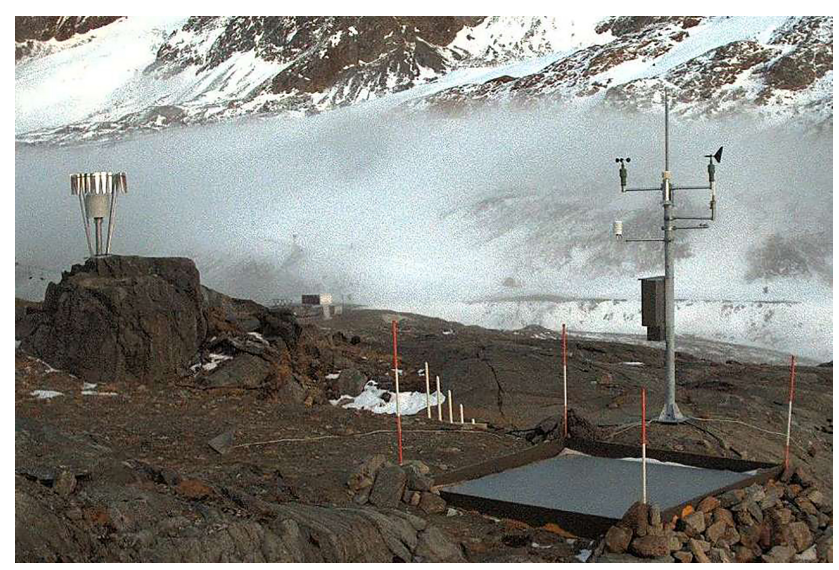

Figure 12. Webcam picture of the Bella Vista weather station $\left(2805 \mathrm{~m}\right.$ a.s.1., $\left.46.78284^{\circ} \mathrm{N}, 10.79138^{\circ} \mathrm{E}\right)$, view to the East. Left: Ott Pluvio 2 with wind shelter. Center: temperature profiler. Right: snow pillow (foreground) and mast with sensors (background) for wind speed and direction, snow height, temperature/humidity and radiative fluxes. The most recent picture is available at http://alpinehydroclimatology.net.

Three additional AWSs are located south of the Rofental, in the Italian Schnalstal: "Teufelsegg" (3035 m a.s.l., $\left.46.7847^{\circ} \mathrm{N}, 10.7647^{\circ} \mathrm{E}\right)$ close to the accumulation area of HEF, “Grawand" (3220 m a.s.1., 46.7703 $\left.{ }^{\circ} \mathrm{N}, 10.7966^{\circ} \mathrm{E}\right)$ in the Schnalstal glacier ski resort and "Vernagt" (1950 m a.s.l., $46.7357^{\circ} \mathrm{N}, 10.8493^{\circ} \mathrm{E}$ ) close to the village and the lake with the same name. These stations are maintained by the Hydrographic Office of the Civil Protection Agency of the Autonomous Province of Bolzano - South Tyrol. Their data are available at http://daten.buergernetz.bz.it/de/dataset/ misure-meteo-e-idrografiche. 
Table 5. Climate and snow variables recorded by the sensors installed at the station Latschbloder $\left(2919 \mathrm{~m}\right.$ a.s.1., $\left.46.80106^{\circ} \mathrm{N}, 10.80659^{\circ} \mathrm{E}\right)$. Accuracy according to technical data sheets of the manufacturers. Original temporal resolution of the data records is $10 \mathrm{~min}$.

\begin{tabular}{|c|c|c|c|c|}
\hline Variable & Sensor & Period of operation & Resolution and accuracy & Unit \\
\hline Air temperature & Vaisala WXT520 & Since September 2013 & $0.1^{\circ} \mathrm{C} \pm 0.3^{\circ} \mathrm{C}$ & ${ }^{\circ} \mathrm{C}$ \\
\hline Relative humidity & Vaisala WXT520 & Since September 2013 & $\begin{array}{l}0.1 \% \pm 3 \% \mathrm{RH} \text { for } 0-90 \% \mathrm{RH} \\
0.1 \% \pm 5 \% \mathrm{RH} \text { for } 90-100 \% \mathrm{RH}\end{array}$ & $\%$ \\
\hline $\begin{array}{l}\text { Wind speed and } \\
\text { direction }\end{array}$ & Vaisala WXT520 & Since September 2013 & $\begin{array}{l}0.1 \mathrm{~m} \mathrm{~s}^{-1} \pm 3 \% \text { (speed) } \\
1^{\circ} \pm 3 \% \text { for } 10 \mathrm{~m} \mathrm{~s}^{-1} \text { (direction) }\end{array}$ & $\begin{array}{l}\mathrm{m} \mathrm{s}^{-1} \\
\text { and }^{\circ}\end{array}$ \\
\hline $\begin{array}{l}\text { Radiative fluxes } \\
\text { (short- and longwave) }\end{array}$ & Kipp \& Zonen CNR 4 & Since September 2013 & $\begin{array}{l}10-20 \mathrm{~W} \mathrm{~m}^{-2} \text { (incoming) } \\
5-15 \mathrm{~W} \mathrm{~m}^{-2} \text { (outgoing) }\end{array}$ & $\mathrm{W} \mathrm{m}^{-2}$ \\
\hline Precipitation & $\begin{array}{l}\text { Vaisala WXT520 } \\
\text { Friedmann tipping bucket } \\
\text { Ott Pluvio } 2 \text { v. } 200 \\
\text { with wind shelter }\end{array}$ & $\begin{array}{l}\text { Since September } 2013 \\
\text { September } 2013 \text { to June } 2014 \\
\text { Since July } 2014\end{array}$ & $\begin{array}{l}0.01 \mathrm{~mm} \mathrm{~h}^{-1} \pm 5 \%{ }^{*} \\
\text { (not yet known) } \\
0.01 \mathrm{~mm} \mathrm{~h}^{-1} \pm 1 \%\end{array}$ & $\mathrm{~mm}$ \\
\hline Atmospheric pressure & Vaisala WXT520 & Since September 2013 & $\begin{array}{l}0.1 \mathrm{hPa} \pm 0.5 \mathrm{hPa} \text { for } 0-30^{\circ} \mathrm{C} \\
0.1 \mathrm{hPa} \pm 1.0 \mathrm{hPa} \text { for }-52-60^{\circ} \mathrm{C}\end{array}$ & $\mathrm{hPa}$ \\
\hline
\end{tabular}

* for hailstorm: $0.1 \mathrm{hit} \mathrm{cm}^{-2}$. The Vaisala WXT520 records rain and hail as well as their durations and intensities, but cannot recognize snowfall. Data 2013: https://doi.org/10.1594/PANGAEA.879215; 2014: https://doi.org/10.1594/PANGAEA.879216; 2015: https://doi.org/10.1594/PANGAEA.879217; 2016 https://doi.org/10.1594/PANGAEA.879218; 2017: https://doi.org/10.1594/PANGAEA.879219.

Table 6. Weather and snow variables recorded by the sensors installed at the station Bella Vista $\left(2805 \mathrm{~m}\right.$ a.s.1., $\left.46.78284^{\circ} \mathrm{N}, 10.79138^{\circ} \mathrm{E}\right)$ Accuracy according to technical data sheets of the manufacturers. Original temporal resolution of the data records is $10 \mathrm{~min}$.

\begin{tabular}{|c|c|c|c|c|}
\hline Variable & Sensor & Period of operation & Resolution and accuracy & Unit \\
\hline Air temperature & $\begin{array}{l}\text { E+E EE08 } \\
\text { Vaisala WXT520 }\end{array}$ & Since July, 2015 & $\begin{array}{l}<0.5^{\circ} \mathrm{C}^{1} \\
0.1^{\circ} \mathrm{C} \pm 0.3^{\circ} \mathrm{C}\end{array}$ & ${ }^{\circ} \mathrm{C}$ \\
\hline Relative humidity & $\begin{array}{l}\text { E+E EE08 } \\
\text { Vaisala WXT520 }\end{array}$ & Since July, 2015 & $\begin{array}{l} \pm 2 \% \mathrm{RH} \text { for } 0-90 \% \mathrm{RH} \\
\pm 3 \% \mathrm{RH} \text { for } 90-100 \% \mathrm{RH} \\
0.1 \% \pm 3 \% \mathrm{RH} \text { for } 0-90 \% \mathrm{RH} \\
0.1 \% \pm 5 \% \mathrm{RH} \text { for } 90-100 \% \mathrm{RH}\end{array}$ & $\%$ \\
\hline Wind speed and direction & $\begin{array}{l}\text { Vaisala WXT520 } \\
\text { Kroneis } 262\end{array}$ & Since July 2015 & $\begin{array}{l}0.1 \mathrm{~m} \mathrm{~s}^{-1} \pm 3 \% \text { (speed) } \\
1^{\circ} \pm 3 \% \text { for } 10 \mathrm{~m} \mathrm{~s}^{-1} \text { (direction) }\end{array}$ & $\mathrm{ms}^{-1}$ and $^{\circ}$ \\
\hline Radiative fluxes & Kipp \& Zonen CNR 4 & Since July 2015 & $\begin{array}{l}10-20 \mathrm{~W} \mathrm{~m}^{-2} \text { (incoming) } \\
5-15 \mathrm{~W} \mathrm{~m}^{-2} \text { (outgoing) }\end{array}$ & $\mathrm{W} \mathrm{m}^{-2}$ \\
\hline Precipitation & $\begin{array}{l}\text { Vaisala WXT520 } \\
\text { Ott Pluvio } 2 \text { v. } 200 \\
\text { with wind shelter }\end{array}$ & $\begin{array}{l}\text { Since July } 2015 \\
\text { Since July, } 2015\end{array}$ & $\begin{array}{l}0.01 \mathrm{~mm} \mathrm{~h}^{-1} \pm 5 \%^{2} \\
0.01 \mathrm{~mm} \mathrm{~h}^{-1} \pm 1 \%\end{array}$ & $\mathrm{~mm}$ \\
\hline Atmospheric pressure & Vaisala WXT520 & Since July, 2015 & $\begin{array}{l}0.1 \mathrm{hPa} \pm 0.5 \mathrm{hPa} \text { for } 0-30^{\circ} \mathrm{C} \\
0.1 \mathrm{hPa} \pm 1.0 \mathrm{hPa} \text { for }-52-60^{\circ} \mathrm{C}\end{array}$ & $\mathrm{hPa}$ \\
\hline Snow water equivalent & Sommer snow pillow $3 \times 3$ & $\left(\right.$ still experimental) ${ }^{3}$ & (still experimental) & $\mathrm{mm}$ \\
\hline Snow depth & Sommer USH-8 & $(\text { still experimental })^{3}$ & $1 \mathrm{~mm} \pm 0.1 \%$ & $\mathrm{~mm}$ \\
\hline Snow temperature & Pilz temperature profiler & $(\text { still experimental })^{3}$ & (still experimental) & ${ }^{\circ} \mathrm{C}$ \\
\hline
\end{tabular}




\subsection{Hydrological data}

\subsubsection{Hintereisferner and Kesselwandferner catchment}

During the International Geophysical years 1957 to 1959 a gauging station was in operation at "Steg Hospiz" (2287 $\mathrm{m}$ a.s.1.), registering the combined streamflow from HEF and KWF (Lang, 1966). The measurements of this campaign are described here as an example for the many short- and longer-term monitoring activities carried out in the Rofental. The Steg Hospiz catchment is $26.6 \mathrm{~km}^{2}$ in size, with a fraction of $58 \%$ being covered by the glaciers at that time. Mean annual recorded streamflow for the catchment area amounted to $1848 \mathrm{~mm}$ (1957-1958) and $1770 \mathrm{~mm}$ (1958-1959), respectively (millimeters are equivalent to liters per square meter per year). Winter runoff (October through March) only was 5 and $10 \%$ of the annual amount, whereas the three summer months (July through September) provided 76 and $72 \%$. Highest mean monthly streamflow amounts were registered in August 1958 (575 mm) and July $1959(559 \mathrm{~mm})$. The frequency distribution of daily streamflow for 1957-1958 shows a period of daily low flows of less than $0.5 \mathrm{~m}^{3} \mathrm{~s}^{-1}\left(18.8 \mathrm{~L} \mathrm{~s}^{-1} \mathrm{~km}^{-2}\right)$ for 217 days (October through May). Higher daily streamflow $>6.0 \mathrm{~m}^{3} \mathrm{~s}^{-1}$ $\left(225 \mathrm{~L} \mathrm{~s}^{-1} \mathrm{~km}^{-2}\right.$ ) only occurred during July and August. The observed maximum daily streamflow was $16.9 \mathrm{~m}^{3} \mathrm{~s}^{-1}$. The glacier contribution, determined as the fraction of (observed) negative mass balance to recorded streamflow, was relatively high in this period: 24 and $20 \%$ of annual streamflow, respectively. The exponential decrease of the hydrograph in fall to the minimum in spring suggests that the winter streamflow mainly originates as delayed meltwater of the previous season from the glaciers. The increase in the water flows after the beginning of the snow melt period occurs with a certain time delay - due to the refreezing of meltwater, and its retention in the snow cover (Lang, 1966).

As of 2017, neither HEF nor KWF are equipped with a permanently registering discharge gauge; this is projected for future initiatives.

\subsubsection{Vernagtferner catchment}

The VF catchment is one of the very few glacierized catchments where simultaneous measurements of glacier mass balance and discharge exist for several decades since 1974 (Escher-Vetter and Reinwarth, 2013). Discharge is measured at the gauge Vernagtbach $\left(46.85675^{\circ} \mathrm{N}, 10.82886^{\circ} \mathrm{E}\right)$, which at $2635 \mathrm{ma}$ a.s.l. is the highest streamflow gauge in Austria (Fig. 13). The water level is continuously monitored in the gauge since 1974, and water-level-to-discharge calibrations are regularly conducted by the salt injection method. The water level is simultaneously determined by three sonic rangers distributed across the runoff channel in order to detect the 2-D surface geometry of the water flow, and surface velocity is monitored by a Doppler system. The total catchment area covers $11.44 \mathrm{~km}^{2}, 7.3 \mathrm{~km}^{2}$ of

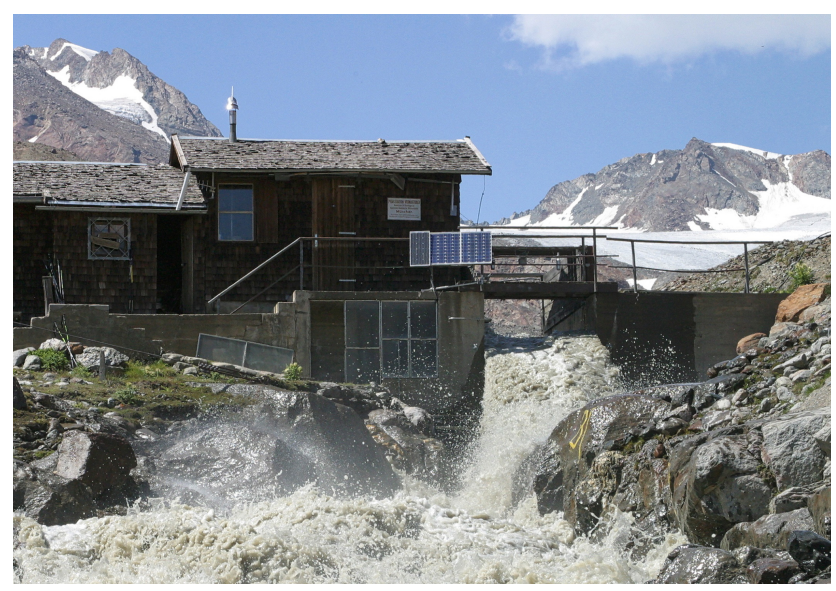

Figure 13. The Vernagtbach gauging station in 2006 (2635 $\mathrm{m}$ a.s.l., $46.85675^{\circ} \mathrm{N}, 10.82886^{\circ} \mathrm{E}$ ), view to the northwest. Photo by Ludwig Braun.

which was glacierized in $2015(63.8 \%)$. The vertical extent ranges from $2635 \mathrm{~m}$ a.s.l. at the gauge to $3635 \mathrm{~m}$ a.s.1. at the summit of "Hinterer Brochkogel" (see also Fig. 4). The discharge values are available as $5 \mathrm{~min}$ values for 2002 to 2012 (https://doi.org/10.1594/PANGAEA.829530). Hourly hydrological records for the Vernagtbach catchment are available for the period 1974 to 2001 at https://doi.org/10.1594/PANGAEA.775113. Monthly averages of discharge are available at https://doi.org/10.1594/PANGAEA.832432, and yearly values are available for the period 1974 to 2012 at https://doi.org/10.1594/PANGAEA.832429.

\subsubsection{Rofental catchment}

Streamflow in the Rofental catchment is recorded at the gauge "Vent-Rofenache" (1891 ma.s.1., 46.85722 $2^{\circ} \mathrm{N}$, $10.91083^{\circ} \mathrm{E}, 98.1 \mathrm{~km}^{2}$ ) at the outlet of the catchment (https://doi.org/10.1594/PANGAEA.876119). VentRofenache is one of the highest operational observation sites of the Hydrographic Service of Tyrol, providing a continuous time series of streamflow and sediment transport recordings since 1967 and 1999, respectively. The regime is dominated by snow melt and ice melt with a significant maximum in July and August (Fig. 14); the glaciated area has decreased from $44 \%$ (in 1969) to $38 \%$ (in 2009; Müller et al., 2009) and is expected to drop to almost zero during the course of the 21 st century, due to the rapidly changing climatic conditions (Hanzer et al., 2017). The coexistence of the Vernagtbach gauge in the VF head watershed allows for combined hydrological investigations. Episodical recordings at smaller tributaries of the Rofenache were obtained during the spring snow melt season in 2014 (Schmieder et al., 2016), and during the glacier melt season in 2016 (Schmieder et al., 2018). 

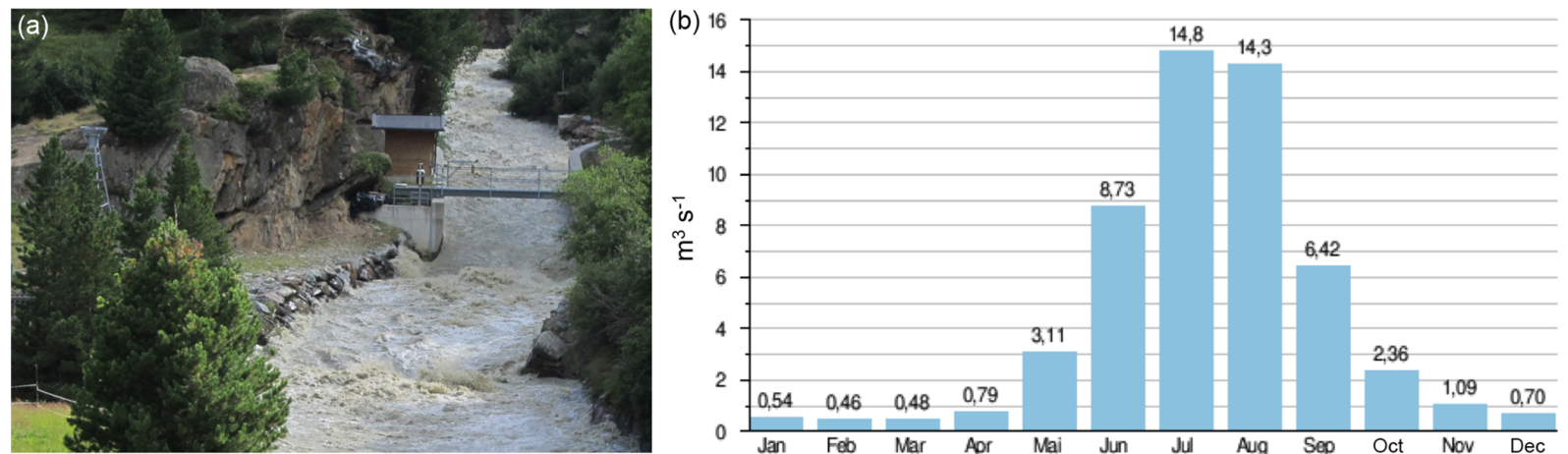

Figure 14. The rainfall totalisator and the gauge at Vent (1891 m a.s.1., $\left.46.85722^{\circ} \mathrm{N}, 10.91083^{\circ} \mathrm{E}\right)$ (a; Photo: Hydrographic Service of the Tyrol), and mean monthly streamflow of the Rofenache 1971-2009 (b). Data from the Hydrographisches Jahrbuch (BMLFUW 2011).

\subsection{Laser scanning data}

Laser scanning is an active remote sensing technique which uses a laser beam to acquire 3-D point data, representing the surface and objects on that surface in high spatial resolution. In addition to high accuracy and resolution, additional information on the spectral properties intensity and reflectance of the scanned surface in the wavelength of the specific scanner is recorded. The DTMs derived from laser scanning measurements are becoming increasingly important for glaciological and geomorphological studies. DTM differencing is an important method for detection and quantification of surface changes and mass budget calculations (Sailer et al., 2014; Klug et al., 2017). Airborne laser scanning (ALS) and terrestrial laser scanning (TLS) are the most common methods for lidar data collection (Telling et al., 2017). The Rofental has been an intensive experimental site for both types of laser scanning data processing and analysis.

\subsubsection{Airborne laser scans}

ALS is well-suited for remote mountain areas, because no external light source is required and, due to overlapping flight strips, the entire surface is captured, even in very steep terrain (Höfle and Rutzinger, 2011). The vertical accuracy is in the order of 0.05 to $0.20 \mathrm{~m}$, mainly dependent on the slope angle (Beraldin et al., 2010; Bollmann et al., 2011). Low vertical errors of $0.05 \mathrm{~m}$ were observed in the HEF catchment for areas with slope angle $<40^{\circ}$ by comparison of an ALS-derived DTM with dGNSS (differential global navigation satellite system) measurements. For the areas with slope angle $>40^{\circ}$, an exponential increase of the vertical error was observed (1.0 $\mathrm{m}$ for $80^{\circ}$, Bollmann et al., 2011; Geist et al., 2005; Sailer et al., 2012).

The HEF data set is built from 21 separate ALS acquisitions from 2001 to 2013, covering an area of $32 \mathrm{~km}^{2}$, including HEF (approx. $6.8 \mathrm{~km}^{2}$ in 2011), KWF (approx. $3.8 \mathrm{~km}^{2}$ in 2011), "Langtaufererjochferner" (approx. $1.1 \mathrm{~km}^{2}$ in 2011) and "Stationsferner" (approx. $0.3 \mathrm{~km}^{2}$ in 2011).
DEMs of $1 \times 1 \mathrm{~m}$ were generated by calculating the $z$ value (altitude) from the mean $z$ value inside the respective grid cell by excluding $5 \%$ of the smallest and largest observations of the ALS points. For the provision of the GeoTIFF (UTM32N) raster files the high-resolution DEMs were resampled to DEMs with a cell size of $10 \times 10 \mathrm{~m}$, applying bilinear interpolation. The resulting DEMs are available at https://doi.org/10.1594/PANGAEA.875889.

The available ALS measurements for HEF were used to study the volume changes of the glacier complementary to direct glaciological surface mass balance measurements. At least one scan was performed at the end of every glacier mass balance year (end of September). From these, a time series of geodetic mass balances was derived for 2001-2002 to 2010-2011 (see Fig. 8). In 2001-2002, 2002-2003, 2007 2008, 2008-2009 and 2010-2011 additional project-based intermediate campaigns were carried out. An overview of the data (UTM32N, WGS84) including the technical details is given in Table 7. Klug et al. (2017) corrected the surface models as well as glacier mass balance data by considering method-inherent uncertainties originating from snow cover, survey dates and density assumptions to calculate corrected annual geodetic mass balances. The most negative balance year is 2002-2003, with a mean specific mass balance of $-2.713 \pm 0.20 \mathrm{~m}$ water equivalent (w.e.). In the subsequent mass balance year 2003-2004, the smallest mass loss is observed (mean specific mass balance $-0.654 \pm 0.09 \mathrm{~m}$ w.e.). For the entire observation period (2001 to 2011) a mean mass balance of $-1.3 \mathrm{~m}$ w.e. was calculated with the HEF ALS data set (Klug et al., 2017).

With the same ALS data sets as described in Table 7, Helfricht et al. (2014b) investigated the spatial snow distribution and its interannual persistence for a partly glacierized mountain area including HEF and KWF $\left(\sim 36 \mathrm{~km}^{2}\right)$. 
Table 7. Overview of the available HEF ALS data with flight date, used Optech sensor, mean flight height above ground (m), maximum scanning angle $\left({ }^{\circ}\right)$, pulse repetition rate $(\mathrm{Hz})$, across-track overlap $(\%)$, mean point density (points $\mathrm{m}^{-2}$ ) and vertical accuracy $(\mathrm{m})$. Data are available at https://doi.org/10.1594/PANGAEA.875889.

\begin{tabular}{|c|c|c|c|c|c|c|c|}
\hline Flight date & $\begin{array}{l}\text { Optech } \\
\text { Sensor }\end{array}$ & $\begin{array}{r}\text { Mean } \\
\text { height above } \\
\text { ground }(\mathrm{m})\end{array}$ & $\begin{array}{r}\text { Maximum } \\
\text { scanning } \\
\text { angle }\left(^{\circ}\right)\end{array}$ & $\begin{array}{r}\text { Pulse } \\
\text { repetition } \\
\text { rate }(\mathrm{Hz})\end{array}$ & $\begin{array}{r}\text { Across-track } \\
\text { overlap }(\%)\end{array}$ & $\begin{array}{r}\text { Mean } \\
\text { point density } \\
\text { (points } \mathrm{m}^{-2} \text { ) }\end{array}$ & $\begin{array}{r}\text { Vertical } \\
\text { accuracy } \\
(\mathrm{m})\end{array}$ \\
\hline 11 Oct 2001 & ALTM 1225 & 900 & 20 & 25000 & 24 & 1.1 & 0.11 \\
\hline 9 Jan 2002 & ALTM 1225 & 900 & 20 & 25000 & 24 & 1.2 & 0.14 \\
\hline 7 May 2002 & ALTM 1225 & 900 & 20 & 25000 & 24 & 1.2 & 0.14 \\
\hline 15 Jun 2002 & ALTM 1225 & 900 & 20 & 25000 & 24 & 1.3 & 0.14 \\
\hline 8 Jul 2002 & ALTM 1225 & 900 & 20 & 25000 & 24 & 1.4 & 0.15 \\
\hline 19 Aug 2002 & ALTM 1225 & 900 & 20 & 25000 & 24 & 1.4 & 0.10 \\
\hline 18 Sep 2002 & ALTM 3033 & 900 & 20 & 33000 & 24 & 1.0 & 0.10 \\
\hline 4 May 2003 & ALTM 2050 & 1150 & 20 & 50000 & 40 & 0.8 & 0.10 \\
\hline 12 Aug 2003 & ALTM 2050 & 1150 & 20 & 50000 & 40 & 0.8 & 0.10 \\
\hline 26 Sep 2003 & ALTM 1225 & 900 & 20 & 25000 & 24 & 1.0 & 0.06 \\
\hline 5 Oct 2004 & ALTM 2050 & 1000 & 20 & 50000 & 24 & 2.0 & 0.07 \\
\hline 12 Oct 2005 & ALTM 3100 & 1000 & 22 & 70000 & $50-70$ & 3.4 & 0.07 \\
\hline 8 Oct 2006 & ALTM 3100 & 1000 & 20 & 70000 & $37-75$ & 2.0 & 0.08 \\
\hline 11 Oct 2007 & ALTM 3100 & 1000 & 20 & 70000 & $37-75$ & 3.4 & 0.06 \\
\hline 9 Sep 2008 & ALTM 3100 & 1000 & 20 & 70000 & $40-45$ & 2.2 & 0.06 \\
\hline 7 May 2009 & ALTM 3100 & - & - & - & - & - & - \\
\hline 30 Sep 2009 & ALTM 3100 & 1100 & 20 & 70000 & $31-66$ & 2.7 & 0.05 \\
\hline 8 Oct 2010 & ALTM Gemini & 1000 & 25 & 70000 & 62 & 3.6 & 0.03 \\
\hline 4 Oct 2011 & ALTM 3100 & 1100 & 20 & 70000 & $25-75$ & 2.9 & 0.04 \\
\hline 11 May 2012 & ALTM 3100 & 1200 & 20 & 70000 & $31-66$ & 2.8 & 0.06 \\
\hline 3 Sep 2013 & ALTM Gemini & 1200 & 20 & 70000 & $59-80$ & 4.2 & 0.04 \\
\hline
\end{tabular}

\subsubsection{Terrestrial laser scans - the permanent laser scanner on Im hintern Eis}

The utility of TLS in performing high-resolution glacier observations was tested for HJF from 2013-2015 when both glaciological and geodetic mass balances were measured. Likewise, a Riegl VZ-6000 TLS was used to produce surface models within $0.1 \mathrm{~m}$ of coincident high-accuracy ALS data for approx. $80 \%$ of the surface of HJF. The TLS surface models are of higher spatial resolution and surface details than the ALS. The TLS data were used - along with coincident optical imagery from the onboard camera - to produce high-resolution surface classifications to map snow-cover extent, and to explore the spatial patterns of the surface mass balance of HJF (Prantl et al., 2017).

In 2016, a permanent TLS was installed in a climate controlled container at $3244 \mathrm{~m}$ a.s.l. close to the summit Im hintern Eis $\left(46.79586^{\circ} \mathrm{N}, 10.78277^{\circ} \mathrm{E}\right)$. The 3-D laser scanner VZ-6000 (manufactured by RIEGL Laser Measurement Systems $\mathrm{GmbH}$ ) offers a long measurement range of more than $6000 \mathrm{~m}$ and operates with beam divergence of $0.12 \mathrm{mrad}$ at a wavelength of $1050 \mathrm{~nm}$, particularly suited for snow- and ice-related applications. The device operates with an angular step width of $0.01^{\circ}$ for a field of view of $60^{\circ}$ vertically and $120^{\circ}$ horizontally and a laser pulse repetition rate of $30 \mathrm{kHz}$, equivalent to an effective measurement rate of
23000 measurements $\mathrm{s}^{-1}$, leading to a point density of approx. $10 \mathrm{pts} \mathrm{m}^{-2}$ for a distance of $1000 \mathrm{~m}$, and to approx. 1 to $2 \mathrm{pts} \mathrm{m}^{-2}$ for the remote areas at a distance of $>3500 \mathrm{~m}$. Hence, the instrument is ideal for static topographic applications such as monitoring of glaciological and geomorphological processes in high mountain terrain. Due to the large field of view, nearly the entire HEF catchment area can be covered by the instrument (Fig. 15); only a very small part of the terminus and small flat areas in the upper glacier zones cannot be sampled. The TLS surface point cloud is accompanied by high-quality optical imagery (5 megapixel). This installation not only allows high temporal and spatial resolution glacier volume changes for HEF to be determined; in addition, the high spatial resolution supports the monitoring of surface features such as crevasses, evolving surface roughness, the supraglacial drainage network and geomorphodynamically induced surface changes (e.g., debris flows) or snow avalanches. Seven scans have been carried out during the test phase (September 2016 to April 2017).

\section{Data availability}

The data sets presented here are available freely from PANGAEA (https://doi.org/10.1594/PANGAEA.876120). The data from the Rofental have been widely used for process studies and all kinds of method and model development ac- 


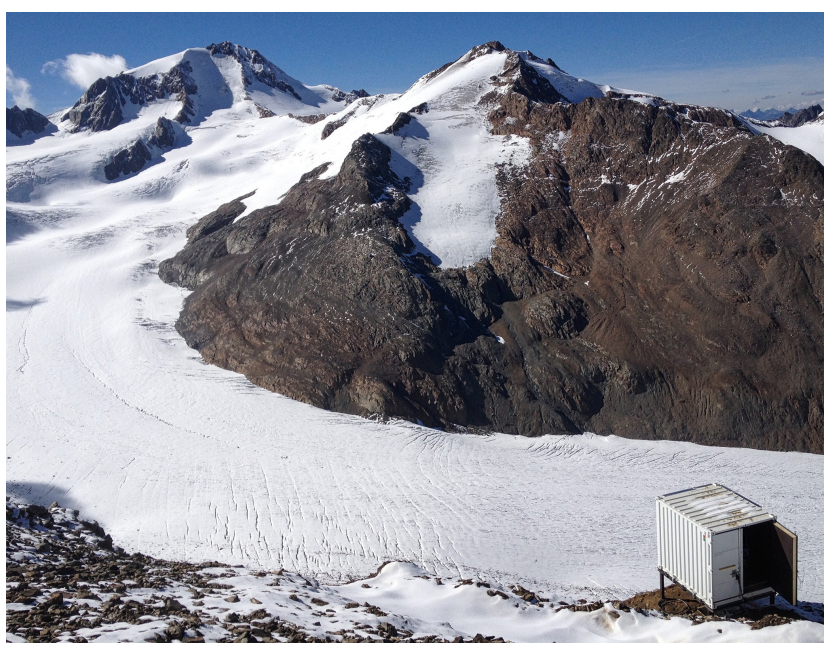

Figure 15. The terrestrial laser scanner in its container housing at Im hintern Eis (3244 m a.s.1., $\left.46.79586^{\circ} \mathrm{N}, 10.78277^{\circ} \mathrm{E}\right)$. View to the west over the upper areas of Hintereisferner to the summit of Weisskugel (3739 m a.s.1.) and Langtauferer Spitze (3529 m a.s.1.). Photo by Rudolf Sailer.

tivities. These data sets, however, represent only a small fraction of what has been observed and collected during the past few decades. Many measurements have been conducted during special field campaigns and are not yet documented for online data publication. For example, hydrological investigations have been conducted in the valley of the Hochjochbach, including streamflow observations with pressure sensors and tracer experiments since 2014 (Schmieder et al., 2016, 2018). Other data await digitization and processing. Originally published in analogue printwork, these data include 3 years of hourly ice temperatures from HEF (Markl and Wagner, 1978), observations of sublimation of ice and snow at HEF (Kaser, 1982, 1983), firn investigations at KWF (Ambach et al., 1978), remote sensing experiments and many energy balance investigations at HEF (Jaffé, 1958, 1960; Hoinkes and Untersteiner, 1952; Hoinkes, 1953a, b; Ambach and Hoinkes, 1963; Wendler, 1967; Kuhn et al., 1979, Wagner, 1979, 1980), and many others. For $\mathrm{VF}$, the situation is similar; a comprehensive overview of the research work has been published by Braun and EscherVetter (2013), including various descriptions and documentations of the used data, methods and models. Older longterm field experiments at VF are described in Moser et al. (1986). Runoff data of the gauge "Vent" have been widely used in hydrological studies, the most recent ones including Schmieder et al. (2016) and Hanzer et al. (2016, 2017). On a regional scale, the Rofental data contributed to modeling exercises for future scenario climatic conditions and their effect on simulated streamflow discharge (Marke et al., 2011, 2013). The Hydrographic Service of Tyrol visualizes its data online at apps.tirol.gv.at/hydro, and provides their download at http://ehyd.gv.at. As of 2017, data of the sites
Latschbloder and Schöne Aussicht are used in several ongoing research projects (listed at http://alpinehydroclimatology. net), and also provide valuable experimental material for application in various student courses.

Several initiatives are also ongoing at the international research network level. Apart from its long history within UNESCO IHP (http://en.unesco.org/themes/water-security/ hydrology), the Rofental recently became a research basin in the framework of the GEWEX INARCH project (http:// words.usask.ca/inarch). It is a research catchment of the ERB Euro-Mediterranean Network of Experimental and Representative Basins (http://erb-network.simdif.com), and a regular complex site in the LTSER platform Tyrolean Alps (http://lter-austria.at/ta-tyrolean-alps), which belongs to the national and international long term ecological research network (LTER Austria, LTER Europe and ILTER). Hintereisferner station is part of the EU Horizon 2020 INTERACT framework of Arctic (and a few Alpine) research stations (https://eu-interact.org/field-sites/station-hintereis/).

The efforts to provide the Rofental data to the scientific community will continue in all of the currently involved institutions.

\section{Conclusions and outlook}

The Rofental in the Ötztal Alps (Austria) is a unique, high Alpine research basin $\left(98.1 \mathrm{~km}^{2}, 1890-3770 \mathrm{~m}\right.$ a.s.l.) with available time series of 150 years of glaciological and hydrometeorological observations. The glaciers in the Rofental attracted early attention and were - for centuries - observed due to the dangerous nature of frequently occurring glacier lake outburst floods. Over the last 100 years, the glacier monitoring has been accompanied by systematic recordings of meteorological and hydrological variables. Today, a glaciological and hydrometeorological data set is available for the Rofental that is without comparison worldwide, with regard to both its amount and temporal coverage. The Rofental data sets support manifold investigations in the context of coupled climate and glacier evolution, snow and glacier hydrology, water resources availability in mountainous regions, or method development like laser scanning or modeling. The scales of such research range from local, like particular micrometeorological assessments at a single observation site, to global, e.g., the estimation of the glacier contribution to sea level rise. This paper gives an overview of what has been measured and what is available already. All the data described are comprehensively documented and made freely available according to the Creative Commons Attribution License by means of the PANGAEA repository (https://doi.org/10.1594/PANGAEA.876120).

This paper covers availability of data as of fall 2017. There are still many manual and analogue historical recordings which are being digitized, processed and documented. After completion they will be made available via PANGAEA and 
will add to the extension of the records back in time (left side of the bars in Fig. 6). New and future data will continue to further build on the available Rofental database (right side of the bars in Fig. 6). This process of continuous enlargement of the data described here is ensured by the living data process as conceived by the journal.

Competing interests. The authors declare that they have no conflict of interest.

Special issue statement. This article is part of the special issue "Hydrometeorological data from mountain and alpine research catchments". It is not associated with a conference.

Acknowledgements. Many of the instruments and the monitoring activities presented here have been supported by the institutions to which the authors are affiliated to, and by countless research programs. These have been funded by the Bavarian Academy of Sciences and Humanities (BAdW), the Deutsche Forschungsgemeinschaft (DFG), the Austrian Academy of Sciences (ÖAW; project HydroGeM ${ }^{3}$ ), the European Region Tyrol - South Tyrol - Trentino (project CRYOMON-SciPro - IPN 10-N33), the Autonomous Province of Bolzano - South Tyrol (project hiSnow 23/40.3), the Austrian Federal Ministry of Agriculture, Forestry, Environment and Water Management (BMLFUW, section IV/4water cycle), and others. The laser data acquisition and processing has been funded by the European Union (project OMEGA - EVK2CT-2000-00069), the Austrian Research Promotion Agency FFG ASAP (Austrian Space Applications Programme; projects ALSX - 815527 and SE.MAP - 840109), the Austrian Research Promotion Agency FFG COMET (Competence Centers for Excellent Technologies) in cooperation with the alpS GmbH (project MUSICALS - 826388), the Austrian Climate Research Programme (ACRP; project C4AUSTRIA - A963633), the Tyrolean Science Foundation (TWF) and the Department of Geography, University of Innsbruck.

All these funding institutions provide the support to continue our efforts in the monitoring of the water balance and climate elements of the Rofental in the long term. The authors gratefully acknowledge all the contributions and support from their countless colleagues in maintaining the instruments in the field, being so many that they cannot be listed here by name. Without their engagement, the long-term monitoring in the Rofental would never have been possible.

Edited by: Danny Marks

Reviewed by: Stefan Pohl, Samuel Morin, Patrick Kormos, and Adam Winstral

\section{References}

Abermann, J., Lambrecht, A., Fischer, A., and Kuhn, M.: Quantifying changes and trends in glacier area and volume in the Austrian Ötztal Alps (1969-1997-2006), The Cryosphere, 3, 205215, https://doi.org/10.5194/tc-3-205-2009, 2009.
Ambach, W. and Hoinkes, H. C.: The heat balance of an Alpine snow field (Kesselwandferner, $3240 \mathrm{~m}$, Oetztal Alps, 1958), IAHS Publ., 61, 24-36, 1963.

Ambach, W., Blumenthaler, M., Eisner, H., Kirchlechner, P., Schneider, H., Behrens, H., Moser, H., Oerter, H., Rauert, W., and Bergmann, H.: Untersuchungen der Wassertafel am Kesselwandferner (Ötztaler Alpen) an einem 30 Meter tiefen Firnschacht, Z. Gletscherkd. Glazialgeol., 14, 61-71, 1978.

Beraldin, J.-A., Blais, F., and Lohr U.: Laser scanning technology, in: Airborne and Terrestrial Laser Scanning, edited by: Vosselman, G. and Maas, H.-G., Whittles Publishing, Dunbeath, UK, $1-42,2010$.

Blümcke, A. and Hess, H.: Der Hochjochferner im Jahre 1883, Zeitschrift des Deutschen und Österreichischen Alpenvereins, Verlag des D. u. Ö. AV, München, 26 pp., 1895.

Blümcke, A. and Hess, H.: Untersuchungen am Hintereisferner, Wissenschaftliche Ergänzungshefte zur Zeitschrift des Deutschen und Österreichischen Alpenvereins, Verlag des D. u. Ö. AV, München, 87 pp., 1899.

BMLFUW: Hydrographisches Jahrbuch von Österreich 2009, Bundesministerium für Land- und Forstwirtschaft, Umwelt und Wasserwirtschaft, Wien, 2011.

Bollmann, E., Sailer, R., Briese, C., Stötter, J., and Fritzmann, P.: Potential of airborne laser scanning for geomorphologic feature and process detection and quantifications in high alpine mountains, Z. Geomorph., 55, 83-104, 2011.

Braun, L. and Escher-Vetter, H. (Eds.): Gletscherforschung am Vernagtferner, Themenband zum fünfzigjährigen Gründungsjubiläum der Kommission für Glaziologie der Bayerischen Akademie der Wissenschaften München, Z. Gletscherkd. Glazialgeol., 45/46, 389 pp., 2013.

Braun, L., Reinwarth, O., and Weber, M.: Der Vernagtferner als Objekt der Gletscherforschung, Z. Gletscherkd. Glazialgeol., 45/46, 85-104, 2013.

Brunner, K.: Karten und Ansichten des Vernagtferners seit 1600, Z. Gletscherkd. Glazialgeol., 45/46, 235-257, 2013.

Charalampidis, C., Braun, L., Fischer, A., Kuhn, M., Lambrecht, A., Mayer, C., Thomaidis, K. and Weber, M.: Effect of glacier geometry on mass loss in a warming climate, J. Geophys. Res.Earth, in review, 2018.

Cogley, J. G., Hock, R., Rasmussen, L. A., Arendt, A. A., Bauder, A., Braithwaite, R. J., Jansson, P., Kaser, G., Müller, M., Nicholson, L., and Zemp, M.: Glossary of Glacier Mass Balance and Related Terms, IHP-VII Technical Documents in Hydrology No. 86, IACS Contribution No. 2, UNESCO-IHP, Paris, 2011.

Escher-Vetter, H. and Oerter, H.: Das Energiebilanz- und Abflussmodel PEV - frühe Modellansätze, Erweiterungen und ausgewählte Ergebnisse, Z. Gletscherkd. Glazialgeol., 45/46, 129-142, 2013.

Escher-Vetter, H. and Reinwarth, O.: Meteorologische und hydrologische Registrierungen an der Pegelstation Vernagtbach - Charateristika und Trends ausgewählter Parameter, Z. Gletscherkd. Glazialgeol., 45/46, 117-128, 2013.

Escher-Vetter, H. and Siebers, M.: Technical comments on the data records from the Vernagtbach station for the period 2002 to 2012, Commission for Geodesy and Glaciology, Section Glaciology Bavarian Academy of Sciences and Humanities, Munich, 2012.

Escher-Vetter, H. and Siebers, M.: Vom Registrierstreifen zur Satellitenübertragung - zur Entwicklung des Mess- und Aufzeich- 
nungsgeräte an der Pegelstation Vernagtbach, Z. Gletscherkd. Glazialgeol., 45/46, 105-116, 2013.

Finsterwalder, S.: Der Vernagtferner, seine Geschichte und seine Vermessung in den Jahren 1888 und 1898, Wissenschaftliche Ergänzungshefte zur Zeitschrift des Deutschen und Österreichischen Alpenvereins, Verlag des D. u. Ö. AV, Graz, 112 pp., 1897.

Fischer, A., Seiser, B., Stocker Waldhuber, M., Mitterer, C., and Abermann, J.: Tracing glacier changes in Austria from the Little Ice Age to the present using a lidar-based high-resolution glacier inventory in Austria, The Cryosphere, 9, 753-766, https://doi.org/10.5194/tc-9-753-2015, 2015

Geist, T. and Stötter, J.: First results on airborne laser scanning technology as a tool for the quantification of glacier mass balance, Proceedings of EARSeL-LISSIG-Workshop Observing our Cryosphere from Space, Bern, Switzerland, 11-13 March 2002.

Geist, T., Elvehøy, H., and Jackson, M.: Investigations on intraannual elevation changes using multi-temporal airborne laser scanning data: case study Engabreen, Norway, Ann. Glaciol. 42, 195-201, https://doi.org/10.3189/172756405781812592, 2005.

Hanzer, F., Helfricht, K., Marke, T., and Strasser, U.: Multilevel spatiotemporal validation of snow/ice mass balance and runoff modeling in glacierized catchments, The Cryosphere, 10, 1859-1881, https://doi.org/10.5194/tc-10-1859-2016, 2016.

Hanzer, F., Förster, K., Nemec, J., and Strasser, U.: Projected cryospheric and hydrological impacts of 21 st century climate change in the Ötztal Alps (Austria) simulated using a physically based approach, Hydrol. Earth Syst. Sci. Discuss., https://doi.org/10.5194/hess-2017-309, in review, 2017.

Harding, R. J., Entrasser, N., Escher-Vetter, H., Jenkins, A., Kaser, M., Kuhn, M., Morris, E. M., and Tanzer, G.: Energy and mass balance studies in the firn area of the Hintereisferner, in: Glacier fluctuations and climatic change, Glaciology and Quaternary Geology, Kluwer, Dordrecht, 325-341, 1989.

Helfricht, K., Kuhn, M., Keuschnig, M., and Heilig, A.: Lidar snow cover studies on glaciers in the Ötztal Alps (Austria): comparison with snow depths calculated from GPR measurements, The Cryosphere, 8, 41-57, https://doi.org/10.5194/tc-8-41-2014, 2014a.

Helfricht, K., Schöber, J., Schneider, K., Sailer, R., and Kuhn, M.: Interannual persistence of the seasonal snow cover in a glacierized catchment, J. Glaciol., 60, 889-904, https://doi.org/10.3189/2014JoG13J197, 2014b.

Hess, H.: Die Gletscher, Nabu Press, Braunschweig, 426 pp., 1904.

Höfle, B. and Rutzinger, M.. Topographic airborne LiDAR in geomorphology: A technological perspective, Z. Geomorph., 55, 1-29, https://doi.org/10.1127/0372-8854/2011/0055S2-0043, 2011.

Hoinkes, H.: Zur Mikrometeorologie der eisnahen Luftschicht, Arch. Met. Geoph. Biokl., 4, 451-458, 1953a.

Hoinkes, H.: Wärmeumsatz und Ablation auf Alpengletschern: II - Hornkees (Zillertaler Alpen), Geogr. Ann., 35, 116-140, https://doi.org/10.1080/20014422.1953.11880853, 1953b.

Hoinkes, H.: Methoden und Möglichkeiten von Massenhaushaltsstudien auf Gletschern, Ergebnisse der Messreihe Hintereisferner (Ötztaler Alpen) 1953-1968, Z. Gletscherkd. Glazialgeol., 6, 37-90, 1970.

Hoinkes H. und Steinacker, R.: Zur Parametrisierung der Beziehung Klima - Gletscher, Rivista Italiana di Geofisica, I, 97-104, 1975.
Hoinkes, H. and Untersteiner, N.: Wärmeumsatz und Ablation auf Alpengletschern I, Vernagtferner (Ötztaler Alpen), August 1950, Geogr. Ann., 34, 99-158, 1952.

Hoinkes, H., Dreiseitl, E., and Wagner, H. P.: Mass Balance of Hintereisferner and Kesselwandferner 1963/64 to 1972/73 in Relation to the Climatic Environment, Preliminary results of the cornbined water, ice and heat balances project in the Rofental, IHDActivities in Austria 1965-1974, Report of the Int. Conference on the Results of the IHD, Paris, 2-14 September 1974, 42-53, 1974.

Jaffé, A.: Neuere Albedo- und Extinktionsmessungen an Gletschereisplatten, Ber. Dt. Wetterdienstes, 54, 273-274, 1958.

Jaffé, A.: Über Strahlungseigenschaften des Gletschereises, Archiv Met. Geoph. Biokl., Edn. 10, 376-395, https://doi.org/10.1007/BF02243201, 1960.

Juen, M., Mayer, C., Lambrecht, A., Eder, K., Wirbel, A., and Stilla, U.: Einsatz einer Thermalkamera und von Strahlungssensoren zur Oberflächenklassifizierung am Vernagtferner, Z. Gletscherkd. Glazialgeol., 45/46, 185-201, 2013.

Kaser, G.: Measurements of Evaporation from Snow, Archiv Met Geoph. Biokl., Ser. B, 30, 333-340, 1982.

Kaser, G.: Über die Verdunstung auf dem Hintereisferner, Z. Gletscherk. Glazialgeol., 19, 149-162, 1983.

Kaser, G., Grosshauser, M., and Marzeion, B.: Contribution potential of glaciers to water availability in different climate regimes, P. Natl. Acad. Sci. USA, 107, 20223-20227, 2010.

Klug, C., Rieg, L., Ott, P., Mössinger, M., Sailer, R., and Stötter, J.: A Multi-Methodological Approach to Determine Permafrost Occurrence and Ground Surface Subsidence in Mountain Terrain, Tyrol, Austria, Permafrost Periglac., 28, 249-265, https://doi.org/10.1002/ppp.1896, 2016.

Klug, C., Bollmann, E., Galos, S. P., Nicholson, L., Prinz, R., Rieg, L., Sailer, R., Stötter, J., and Kaser, G.: A reanalysis of one decade of the mass balance series on Hintereisferner, Ötztal Alps, Austria: a detailed view into annual geodetic and glaciological observations, The Cryosphere Discuss., https://doi.org/10.5194/tc-2017-132, in review, 2017.

Kreuss, O.: Compiled geological map of ÖK50 Sheet 173 - Sölden, preliminary GEOFAST 1:50000 edition 2016/03, Geologische Bundesanstalt Wien Publishing House, 2012.

Kuhn, M.: Micro-meteorological conditions for snow melt, J. Glaciol., 33, 24-26, 1987.

Kuhn, M., Kaser, G., Markl, G., Wagner, H. P., and Schneider, H. (Eds.): 25 Jahre Massenhaushaltsuntersuchungen am Hintereisferner, Auszug aus den glazialmeteorologischen Arbeiten im Gebiet des Hintereisferners in den Ötztaler Alpen, Institut für Meteorologie und Geophysik der Universität Innsbruck, 80 pp., 1979.

Kuhn, M., Kaser, G., Markl, G., Nickus, U., and Obleitner, F.: Fluctuations of Mass Balance and Climate: The 30 Years Record of Hintereis- and Kesselwandferner, Z. Gletscherkd. Glazialgeol., 22, 490-416, 1985a.

Kuhn, M., Markl, G., Kaser, G., Nickus, U., Obleitner, F., and Schneider, H.: Fluctuations of climate and mass balances: Different responses of two adjacent glaciers, Z. Gletscherkd. Glazialgeol., 21, 409-416, 1985b.

Kuhn, M., Dreiseitl, E., Hofinger, S., Markl, G., Span, N., and Kaser, G.: Measurements and models of the mass 
balance of Hintereisferner, Geogr. Ann. A, 81, 659-670, https://doi.org/10.1111/1468-0459.00094, 1999.

Kuhn, M., Abermann, J., Olefs, M., Fischer, A., and Lambrecht, A.: Gletscher im Klimawandel: Aktuelle Monitoring- programme und Forschungen zur Auswirkung auf den Gebietsabfluss im Ötztal, Mitt. hydr. Dienst Österr., 86, 31-47, 2006.

Kuhn, M., Lambrecht, A., Abermann, J., Patzelt, G., and Groß, G.: Die österreichischen Gletscher 1998 und 1969, Flächen- und Volumenänderungen, Verlag der österr. Akad. Wiss., Wien, available at: hw.oeaw.ac.at/6616-0, 128 pp., 2009.

Kuhn, M., Lambrecht, A., Abermann, J., Patzelt, G., and Groß, G.: The Austrian Glaciers 1998 and 1969, Area and Volume Changes, Z. Gletscherkd. Glazialgeol., 43/44, 3-107, 2012.

Lambrecht, A. and Kuhn, M.: Glacier changes in the Austrian Alps during the last three decades, derived from the new Austrian glacier inventory, Ann. Glaciol., 46, 177-184, https://doi.org/10.3189/172756407782871341, 2007.

Lang, H.: Hydrometeorologische Ergebnisse aus Abflußmessungen im Bereich des Hintereisferners (Ötztaler Alpen) in den Jahren 1957-1959, Archiv Met. Geoph. Biokl. B, 14, 280-302, 1966.

Lauffer, I.: Das Klima von Vent, Dissertation, University of Innsbruck, available at: http://acinn.uibk.ac.at/sites/default/files/ Diss_Lauffer_Ingrid_1966.pdf, 1966.

Lindmayer, A.: Untersuchung zum Einfluss der Veränderung der Topographie der Eisoberfläche auf die spezifische Massenbilanz eines Gletschers am Beispiel des Vernagtferners im Zeitraum 1889-1938, Master Thesis, Catholic University of Eichstätt-Ingolstadt, Faculty of Mathematics and Geography, 102 pp., available at: http://kegglaziologie.de/download/MSc_ A_Lindmayer2015.pdf (last access: 26 November 2017), 2015.

Marke, T., Mauser, W., Pfeiffer, A., and Zängl, G.: A pragmatic approach for the downscaling and bias correction of regional climate simulations: evaluation in hydrological modeling, Geosci. Model Dev., 4, 759-770, https://doi.org/10.5194/gmd-4759-2011, 2011.

Marke, T., Mauser, W., Pfeiffer, A., Zängl, G., Jacob, D., and Strasser, U.: Application of a hydrometeorological model chain to investigate the effect of global boundaries and downscaling on simulated river discharge, Environ. Earth Sci., 71/11, 48494846, https://doi.org/10.1007/s12665-013-2876-z, 2013.

Markl, G. and Wagner, H. P.: Messungen von Eis- und Firntemperaturen am Hintereisferner (Ötztaler Alpen), Symposium über die Dynamik temperierter Gletscher, Z. Gletscherkd. Glazialgeol., 13, 261-265, 1978.

Marzeion, B. and Levermann, A.: Loss of cultural world heritage and currently inhabited places to sea-level rise, Environ. Res. Lett., 9, 051001, https://doi.org/10.1088/1748-9326/9/3/034001, 2014.

Marzeion, B. and Kaser, G.: Peak Water: An Unsustainable Increase in Water Availability From Melting Glaciers, Mountains and climate change: A global concern, Centre for Development and Environment (CDE), Swiss Agency for Development and Cooperation (SDC) and Geographica Bernensia, Bern, 47-50, 2014.

Marzeion, B., Jarosch, A. H., and Hofer, M.: Past and future sealevel change from the surface mass balance of glaciers, The Cryosphere, 6, 1295-1322, https://doi.org/10.5194/tc-6-12952012, 2012a.

Marzeion, B., Hofer, M., Jarosch, A. H., Kaser, G., and Mölg, T.: A minimal model for reconstructing interannual mass balance variability of glaciers in the European Alps, The Cryosphere, 6, 71-84, https://doi.org/10.5194/tc-6-71-2012, 2012b.

Marzeion, B., Cogley, J. G., Richter, K., and Parkes, D.: Attribution of global glacier mass loss to anthropogenic and natural causes, Science, 345, 919-921, https://doi.org/10.1126/science.1254702, 2014a.

Marzeion, B., Jarosch, A. H., and Gregory, J. M.: Feedbacks and mechanisms affecting the global sensitivity of glaciers to climate change, The Cryosphere, 8, 59-71, https://doi.org/10.5194/tc-859-2014, 2014b.

Mayer, C., Escher-Vetter, H., and Weber, M.: 46 Jahre glaziologische Massenbilanz des Vernagtferners, Z. Gletscherkd. Glazialgeol., 45/46, 219-234, 2013a.

Mayer, C., Lambrecht, A., Blumthaler, U., and Eisen, O.: Vermessung und Eisdynamik des Vernagtferners, Ötztaler Alpen, Z. Gletscherkd. Glazialgeol., 45/46, 259-280, 2013b.

Morin, S., Lejeune, Y., Lesaffre, B., Panel, J.-M., Poncet, D., David, P., and Sudul, M.: An 18-yr long (1993-2011) snow and meteorological dataset from a mid-altitude mountain site (Col de Porte, France, $1325 \mathrm{~m}$ alt.) for driving and evaluating snowpack models, Earth Syst. Sci. Data, 4, 13-21, https://doi.org/10.5194/essd4-13-2012, 2012.

Moser, H., Escher-Vetter, H., Oerter, H., Reinwarth, O., and Zunke, D.: Abfluß in und von Gletschern, Technical University of Munich (TUM), Special Research Report 81, Final Report Project A1, GSF-Bericht, 41/86, 1-397, 1986.

Moser, M.: Compiled geological map of ÖK50 Sheet 172 Weißkugel, preliminary GEOFAST 1:50000 edition 2016/03, Geologische Bundesanstalt Wien, Publishing House, 2012.

Müller, G., Godina, R., and Gattermayer, W.: Der Pegel Vent/Rofenache - Herausforderungen für eine hydrographische Messstelle in einem vergletscherten Einzugsgebiet, Mitt. hydr. Dienst Österr., 86, 131-135, 2009.

Nicolussi, K.: Bilddokumente zur Geschichte des Vernagtferners im 17. Jahrhundert, Z. Gletscherkd. Glazialgeol., 26, 97-119, 1990.

Nicolussi, K.: Die historischen Vorstöße und Hochstände des Vernagtferners, Z. Gletscherkd. Glazialgeol., 45/46, 9-23, 2013.

Obleitner, F.: Climatological features of glacier and valley winds at the Hintereisferner (Ötztal Alps, Austria), Theor. Appl. Climatol., 49, 225-239, 1994.

Painter, T. H., Flanner, M. G., Kaser, G., Marzeion, B., VanCuren, R. A., and Abdalati, W.: End of the Little Ice Age in the Alps forced by industrial black carbon, P. Natl. Acad. Sci. USA, 110, 15216-15221, https://doi.org/10.1073/pnas.1302570110, 2013.

Prantl, H., Nicholson, L., Sailer, R., Hanzer, F., Juen, I., and Rastner, P.: Glacier snowline determination from terrestrial laser scanning intensity data, Geosciences, 7, 1-21, https://doi.org/10.3390/geosciences7030060, 2017.

Prasch, M., Marke, T., Strasser, U., and Mauser, W.: Large scale integrated hydrological modelling of the impact of climate change on the water balance with DANUBIA, Adv. Sci. Res., 7, 61-70, https://doi.org/10.5194/asr-7-61-2011, 2011.

Richter, E.: Urkunden über die Ausbrüche des Vernagt- und Gurglergletschers im 17. und 18. Jahrhundert, Forschungen zur deutschen Landes- und Volkskunde, 6, edited by: Engelhorn, J., Stuttgart, 345-440, 1892.

Sailer, R., Bollmann, E., Hoinkes, S., Rieg, L., Sproß, M., and Stötter, J.: Quantification of Geomorphodynamics in glaciated and recently deglaciated terrain based on airborne laserscanning 
data, Geogr. Ann. A, 94, 17-32, https://doi.org/10.1111/j.14680459.2012.00456.x, 2012.

Sailer, R., Rutzinger, M., Rieg, L., and Wichmann, V.: Digital elevation models derived from airborne laser scanning point clouds: appropriate spatial resolutions for multitemporal characterization and quantification of geomorphological processes, Earth Surf. Proc. Landf. 39, 272-284, https://doi.org/10.1002/esp.3490, 2014.

Schmieder, J., Hanzer, F., Marke, T., Garvelmann, J., Warscher, M., Kunstmann, H., and Strasser, U.: The importance of snowmelt spatiotemporal variability for isotope-based hydrograph separation in a high-elevation catchment, Hydrol. Earth Syst. Sci., 20, 5015-5033, https://doi.org/10.5194/hess-20-5015-2016, 2016.

Schmieder, J., Garvelmann, J., Marke, T., and Strasser, U.: Spatiotemporal tracer variability in the glacier melt end-member - How does it affect hydrograph separation results?, Hydrol. Process., in review, 2018.

Schöber, J., Schneider, K., Helfricht, K., Schattan, P., Achleitner, S., Schöberl, F., and Kirnbauer, R.: Snow cover characteristics in a glacierized catchment in the Tyrolean Alps - Improved spatially distributed modelling by usage of Lidar data, J. Hydrol., 519, 3492-3510, 2014.

Schöber, J., Achleitner, S., Bellinger, J., Kirnbauer, R., and Schöberl, F.: Analysis and modelling of snow bulk density in the Tyrolean Alps, Hydrol. Res., 47, 419-441, https://doi.org/10.2166/nh.2015.132, 2016.

Siogas, L.: Die Windverhältnisse an der Station Hintereis (3026 m) in den Ötztaler Alpen, Archiv Met. Geoph. Biokl. B, 25, 79-89, 1977a.

Siogas, L.: Die Luftdruckreihe Vent 1935-1970, Eine Analyse des jahres- u. tagesperiodischen sowie des aperiodischen Schwankungsverhaltens an einer inneralpinen Talstation im Vergleich zu anderen Stationen des Alpenraumes, Dissertation, University of Innsbruck, 150 pp., $1977 \mathrm{~b}$.

Telling, J., Lyda, A., Hartzell, P., and Glennie, C.: Review of Earth science research using terrestrial laser scanning, Earth-Sci. Rev. 169, 35-68, https://doi.org/10.1016/j.earscirev.2017.04.007, 2017.
Wagner, H.-P.: Strahlungshaushaltsuntersuchungen an einem Ostalpengletscher während der Hauptablationsperiode, Teil 1, Kurzwellige Strahlung, Archiv Met. Geoph. Biokl. B, 27, 297324, 1979.

Wagner, H.-P.: Strahlungshaushaltsuntersuchungen an einem Ostalpengletscher während der Hauptablationsperiode, Teil 2, Langwellige Strahlung und Strahlungsbilanz, Archiv Met. Geoph. Biokl. B, 28, 41-62, 1980.

Weber, M.: Dokumentation der Veränderungen des Vernagtferners und des Guslarferners anhand von Fotografien, Z. Gletscherkd. Glazialgeol., 45/46, 49-84, 2013.

Weber, M., Braun, L., Mauser, W., and Prasch, M.: Die Bedeutung der Gletscherschmelze für den Abfluss der Donau gegenwärtig und in der Zukunft, Mitt. hydr. Dienst Österr., 86, 1-29, 2009.

Weber, M. and Prasch, M.: Influence of the glaciers on runoff regime and its change, chap. 56, in: Regional assessment of global change impacts, edited by: Mauser, W. and Prasch, M., Springer, Berlin, 493-509, 2015a.

Weber, M. and Prasch, M.: The influence of snow cover on runoff regime and its change, chap. 60, in: Regional assessment of global change impacts, edited by: Mauser, W. and Prasch, M., Springer, Berlin, 533-539, 2015b.

Wendler, G.: Die Vergletscherung in Abhängigkeit von Exposition und Höhe und der Gebietsniederschlag im Einzugsgebiet des Pegels Vent in Tirol, Archiv Met. Geoph. Biokl. B, 15, 260-273, 1967.

Zemp, M., Thibert, E., Huss, M., Stumm, D., Rolstad Denby, C., Nuth, C., Nussbaumer, S. U., Moholdt, G., Mercer, A., Mayer, C., Joerg, P. C., Jansson, P., Hynek, B., Fischer, A., Escher-Vetter, H., Elvehøy, H., and Andreassen, L. M.: Reanalysing glacier mass balance measurement series, The Cryosphere, 7, 12271245, https://doi.org/10.5194/tc-7-1227-2013, 2013. 